Revista de Estudios Histórico-Jurídicos

[Sección Derecho Romano]

XXXI (Valparaíso, Chile, 2009)

[pp. 87 - 123]

\title{
LA CIUDADANÍA ROMANA BAJO LOS SEVEROS
}

["The Roman Citizenship under the Severans"]

\author{
EDUARDo ANDRADEs Rivas* \\ Universidad del Desarrollo
}

\section{RESUMEN}

El artículo trata el tema de la culminación del proceso de extensión de la ciudadanía romana bajo la dinastía de los Severos. Se analiza el origen y el gobierno de Septimio Severo y sus sucesores, especialmente el de Caracalla, y las principales decisiones de su gobierno referentes a la ciudadanía, con especial énfasis en la Constitución Antoniniana, sus diversas interpretaciones históricas y su significado político cultural. Finalmente se hace referencia a la transformación de la noción de ciudadanía en el concepto de súbditos en el Bajo Imperio.

Palabras clave: Ciudadanía romana - Severos - Ciudad - Romanización Cultura Romana - Civilización Urbana Septimio Severo-Caracalla-Constitución Antoniniana.

\section{Abstract}

This paper presents the subject of the expansion process of roman citizenship culminating in the Severan Dynasty. The origin and government of Septimius Severus and its successors are analyzed, especially those of Caracalla, studying the main decisions of his government related to citizenship, emphasizing the Constitutio Antoniniana and its various historical interpretations and it is political and cultural significance. Finally, the article mentions the transformation of the meaning of citizenship in the subject concept under the Late Empire.

KeYwORDS: Roman citizenship - Severan - City - Romanization - Roman Culture - Urban Civilisation - Septimius Severus Caracalla - Constitutio Antoniana.

* Profesor titular de Historia del Derecho y Cultura Occidental en las Facultades de Derecho y Gobierno de la Universidad del Desarrollo. Dirección postal: Ainavillo 456, 5o piso, Concepción, Chile. Correo electrónico: eandrade@udd.cl. 


\section{INTRODUCCIÓN}

Cuando Roma conquistaba un nuevo territorio, romanizaba. Es decir, convertía en romanos a los pueblos que conquistaba ${ }^{1}$. Hemos tenido oportunidad de ver cómo esta política de expansión de la cultura y la manera romana de ver el mundo, el orbis terrarum, tuvo en la concesión de la ciudadanía romana un vehículo de primerísima importancia para el logro de aquella meta ${ }^{2}$.

Y en la lógica de la romanización, Roma se valió de la ciudadanía para difundir no solo los grandes principios de sus instituciones jurídicas, sino sus concepciones políticas, sus usos y tradiciones, desde su lengua hasta sus vestiduras y forma de hablar.

El camino en la ampliación de la ciudadanía había avanzado desde los tiempos de Cayo Mario, los Julio Claudios, los Flavios y Antoninos y la permanente política de los dirigentes romanos en esta materia se encontraba pronta a producir sus más importantes frutos. Cientos de miles de romanos, auténticos miembros de la cultura latina, habitaban en todas las márgenes del Imperio, aunque por sus venas no corriera una sola gota de sangre italiana. Era el resultado que se había producido tras más de dos siglos de ampliación de los derechos que importaba la ciudadanía. Y aunque esos romanos de rasgos morenos que habitaban Alejandría o Leptis Magna; de tez olivácea en las decápolis de Jerasa o Palmira; o de pálida piel y rubios cabellos en Eboracum, pudieran resultar extraños a los antiguos patricios de la Urbe, no era menos cierto que sus costumbres, su modo de pensar y organizar su vida y negocios era indudablemente romano ${ }^{3}$. Tan romano que los grandes Antoninos habían provenido de Hispania ${ }^{4}$ y la Galia narbonense ${ }^{5}$, pero nadie hubiera afirmado que eran menos romanos que los nacidos en la Urbe.

${ }^{1}$ Véase: Dawson, Christopher, Historia de la cultura cristiana (1950, trad. cast. México, 1997), p. 73: "Fue tarea de Roma extender a Occidente esta tradición de civilización superior; ella fue la mediadora entre el civilizado mundo helenístico del Mediterráneo oriental y los pueblos bárbaros de Europa Occidental."

${ }^{2}$ Con el presente trabajo concluimos una serie de tres estudios destinados a la ciudadanía romana y su concesión como instrumento de expansión cultural o romanización. Véase: ANDRADES RIVAS, Eduardo, La ciudadanía romana bajo los Julio-Claudios en Revista de Estudios Histórico-Jurídicos 29 (2007), pp. 165-208; y El MISMO, La ciudadania romana bajo los Flavios y Antoninos en Revista de Estudios Histórico-Jurídicos 30 (2008), pp. 47-80.

${ }^{3}$ Muestra de esta profunda integración cultural es la práctica, seguida a lo largo y ancho de todo el orbe romano, de adoptar nombres romanos, aunque conservando, en un comienzo el cognomen de la patria original, para olvidarlo por completo más adelante. Nombres con extrañas combinaciones fonéticas como Elio Adriano Kalícrates o Publio Flavio Arbasates resultaban así frecuentes en los territorios imperiales de oriente. Al respecto consultar GiUA, Maria Antonietta, recensión a Dondin-PAYRe, Monique y RaEPSAET-ChAnlier, Marie-Thérèse (editoras), Noms. Identités culturelles et Romanisation sous le Haut-Empire, en Athenaeum, Studi di Letteratura e Storia dell'Antichità 92 (2004) 1, pp. 313-321; y Pérez Almogera, Arturo, "Civitates" y etnias epónimos en el área ibérica: las excepciones (Contestani, Lacetani, Cerretani), en Florentia Iliberritana. Revista de Estudios de Antigüedad Clásica 11 (2000), pp. 195-213.

${ }^{4}$ César Marco Ulpio Trajano Augusto (53-98-117) y Publio Elio Trajano Adriano Augusto (76-117-138). A los dos anteriores debemos agregar el nombre de Marco Aurelio Antonino Augusto (121-161-180), cuyo padre biológico, Marco Annio Vero, fue hispano.

${ }^{5}$ Tito Elio Adriano Antonino Pío Augusto (86-138-161). 
Ahora un nuevo emperador entraba en Roma para poner fin a la confrontación y los desórdenes producidos por Cómodo ${ }^{6}(192)$ y sus inmediatos sucesores ${ }^{7}$. Con él se iniciaba un nuevo periodo de paz, aunque por desgracia esta sería demasiado breve para restaurar al Imperio a los fastos del saeculum aureum. Este nuevo príncipe provenía de las lejanas tierras del sur. Se trataba de Septimio Severo ${ }^{8}$, un talentoso general, cabeza de una familia originaria de Leptis Magna, ciudad cercana a Cartago en la provincia de África.

Bajo la dinastía que inauguraba Septimio, se produciría el cambio definitivo en materia de ciudadanía que estudiamos en el presente trabajo. Pero los efectos de dicho cambio se harían visibles solo con el paso de los años.

Tras el asesinato de Alejandro Severo 9 (235), especialmente desde el gobierno de Diocleciano ${ }^{10}$ se produciría una lenta pero definitiva transformación del régimen político romano, desde las formas republicanas aparentes en el Principado, hasta la adopción de una forma más o menos evidente de despotismo oriental, que afectaría directamente a la noción de ciudadanía. De hecho, en este periodo es posible asistir a la transformación del ciudadano en el súbdito de los últimos años del Imperio occidental.

El momento final de la ciudadanía, como idea de cultura política y social coincide con el reinado de Teodosio el Grande. Un breve análisis del panegírico de Pacato nos permitirá apreciar cuanto quedaba en los tiempos del último de los grandes césares de la idea que motivó este estudio.

Para concluir revisamos la influencia que la noción de ciudadanía romana ha tenido desde los años del Imperio hasta nuestros propios días, en otras experiencias imperiales. Podemos repetir con legitimidad la afirmación de Ulpiano "In Orbe Romano qui sunt, ex Constitutione imperatoris Antonini cives Romani effecti sunt" ${ }^{11}$. Es que Roma ha animado el espíritu de los occidentales a lo largo de todos los siglos que nos separan de la ciudad de Octavio y Marco Aurelio ${ }^{12}$. Los ideales de la Iglesia Católica en las Cruzadas, la creación del Sacro Imperio "Romano" y Germánico, el despertar del poder europeo en el siglo XV con el

${ }^{6}$ Lucio Aurelio Cómodo Antonino (161-180-192).

${ }^{7}$ Los historiadores clásicos han dado a este periodo, el año 193, el nombre de "año de los cinco emperadores”. Pértinax, sucesor de Cómodo, fue a su vez sucedido por Didio Juliano, quien fue desafiado por Pescenio Níger y por Clodio Albino, todos los cuales fueron finalmente vencidos por Septimio Severo.

${ }^{8}$ César Lucio Septimio Severo Pértinax Augusto (146-193-211).

${ }^{9}$ Marco Aurelio Severo Alejandro (208-222-235) último de los miembros de esta dinastía en el trono del Imperio.

${ }^{10}$ Gayo Aurelio Valerio Diocleciano (245-311). Reina entre los años 284 a 305.

${ }^{11}$ Ulpiano, Digesto, 1,5,17.

${ }^{12}$ Bermejo Barrera, José Carlos - Piedras Monroy, Pedro Andrés, Genealogía de la Historia, ensayos de historia teórica (Madrid, 1999), III, p. 17: "Lo que Roma sí que aportará como innovación en autores como Tito Livio será la idea, tomada de Polibio, de que el pueblo romano ha logrado plasmar una forma política estable, dotada además de una enorme capacidad de adaptación y destinada a perdurar indefinidamente. Se trata de la idea de Roma Aeterna, que poseerá una gran porvenir en la teoría política medieval y que sobrevivirá encarnada en formas políticas muy alejadas de lo que fue el Imperio Romano, como lo fueron el Imperio Bizantino, el sacro Imperio Romano Germánico o la institución del Zar entre los rusos”. 
Imperio Hispánico, el Turco e incluso el surgimiento del Imperio Británico son deudores directos de la concepción cultural romana de la ciudadanía ${ }^{13}$.

\section{ESTADO DE LA CUESTIÓN}

Con la expresión "ciudadano del Imperio" los romanos aluden a un modo de vida, más precisamente a su modo de vida, la única que un hombre educado del mundo antiguo entiende que es posible para el ser humano, la vida de la ciudad o civitas $^{14}$.

Es la ciudad el origen y punto de desarrollo de toda cultura. En la vida rural el hombre no logra sino un desarrollo cultural y mental incompleto. Giardina lo ha recordado perfectamente, al describir la reacción que un habitante de la urbe tendría hacia un hombre criado en el mundo rural. Se les trata de rústicos, agrestes, cuya falta de 'urbanidad' se denota en cada acción que acometen ${ }^{15}$.

Como hemos dicho sobre esta materia en otras oportunidades, para la cultura romana la noción de ciudadanía era mucho más que un concepto jurídico, se trata de una forma de vida, de cómo un hombre experimenta los privilegios de la educación urbana y finalmente, de cómo se contempla a sí mismo.

Esta forma de verse a sí mismos y de ver el mundo que los rodeaba llevó a los romanos a considerar a la ciudadanía como un factor de unidad. Como decíamos al inicio de estas explicaciones, ciudadanos romanos de la más variada apariencia

${ }^{13}$ Ya lo decía Arnold, E. V., Classics and Citizenship, en The Classical Quarterly 14 (1920) 2, pp. 78-81, tras la primera guerra mundial: "El estudio de los clásicos es indispensable para entender el presente, pues nosotros mismos somos herederos de su cultura".

${ }^{14}$ Sobre el particular dice Dawson, Christopher, cit. (n. 1), p. 78: "A primera vista, lo que más impresiona es el aspecto militar de la obra de Roma, pero para la historia de la cultura es todavía más importante el proceso civil de urbanización. La principal misión de Roma fue introducir la ciudad en la Europa continental, y con la ciudad vinieron la idea de ciudadanía y la tradición cívica, que ha sido la más grande creación de la cultura mediterránea. El soldado romano y el ingeniero militar fueron los agentes de este proceso de expansión; en realidad, Augusto organizó el ejército como preparación para la vida civil y como agente de difusión de la cultura y las instituciones romanas en las nuevas provincias.

${ }^{15}$ Giardina, Andrea, “Introducción”, en El MISMO (editor), El hombre romano (Madrid, 1989), p. 17: “[...] había ciudadanos romanos que un romano de cultura media difícilmente hubiera reconocido como tales. Eran, por ejemplo, los individuos que se hacían acreedores de los calificativos de rusticus y agrestis, que comprendían los campesinos no urbanizados, los pastores y, en general, todas las gentes de los espacios abiertos. Para los que vivían en la ciudad existían ciertas dificultades para reconocer como semejantes los individuos (que eran la mayoría) que, al vivir en los campos, en los pastos y en los bosques, se habían alejado demasiado de los parámetros medios del comportamiento civil. Las connotaciones físicas del tipo agrestis, rusticus, montanus nos remiten a un tipo hirsuto y con los dientes negros, que apesta a cabra, a ajo y a sopa; este tipo humano se reconocía a primera vista por la indumentaria, por la cabellera demasiado larga (que nunca fue "un signo de virtud", y que le hacía asemejarse a los bárbaros), o bien, en sentido contrario, por los cabellos demasiado cortos, rapados al cero; por el modo de hablar, que provocaba la risa, por el tono excesivamente alto de la voz, y, sobre todo, por el continente: por ejemplo, le era propia cierta arritmia, que contrastaba con la andadura acompasada y lenta que caracterizaba, en cambio, al buen ciudadano; se le reconocía por el modo de sentarse y por la gesticulación desarticulada de sus manos no educadas". 
física, de usos y tradiciones familiares por demás diversas, se consideraban parte de un mismo mundo, un mismo orden jurídico, el orbis terrarum o mundo civilizado.

Siguiendo nuestra línea de investigación precedente, hemos contrastado las fuentes primarias de que disponemos con las más clásicas obras de estudio de Roma y su Imperio. Asimismo hemos tratado de consultar la bibliografía más representativa del enorme caudal académico que se ha producido en el último siglo sobre el Papiro de Giessen y la Constitución Antoniniana.

Debemos tener siempre presente que nuestro objetivo es comprobar que la concesión de la ciudadanía romana fue mucho más que un elemento igualador de carácter jurídico, aunque esta faz del tema resulta ineludible, por lo que la trataremos con la debida atención. Intentamos, ante todo, demostrar que, gracias a la labor de los Severos (y a sus predecesores en la dirección del Imperio), la ciudadanía resultaba sinónimo de ser aceptado plenamente en la cultura romana, en la cultura cívica que caracterizaba lo mejor del mundo antiguo.

En suma, el presente estudio abordará las dos caras de la misma moneda: la concesión de la ciudadanía romana con la romanización de los habitantes de los más remotos rincones del Imperio. A mayor cantidad de ciudadanos romanos, más vida urbana, más civilización romana y mayor influencia de dicha cultura sobre los diversos pueblos que formaron el mundo mediterráneo. El análisis de las fuentes, contrastadas con la historiografía especializada es la base de nuestro trabajo, el que se complementa con aportes provenientes de la epigrafía y papirología.

La presente investigación se ha desarrollado de acuerdo con las siguientes modalidades:

i) Se han estudiado fuentes directas, es decir, documentos clásicos traducidos al español. En total se han analizado 8 fuentes históricas y jurídicas ${ }^{16}$. Particularmente importante para nuestro análisis es el Papiro de Giessen que examinamos cuidadosamente en sus implicancias y consecuencias jurídico culturales, se trata del documento que da testimonio de la Constitutio Antoniniana de civitate $^{17}$ de 212 ,

${ }^{16}$ Ellas son: Herodiano, Historia del imperio romano después de Marco Aurelio; MenANDro el rétor, Dos tratados de retórica epidíctica; Varios Autores, Historia Augusta; Agustín, San, La Ciudad de Dios; Justiniano, Cuerpo del Derecho Civil Romano, Instituciones; Justiniano, Cuerpo del Derecho Civil Romano, Digesto; Latinio PaCato Drepanio, Panegyricus Latini Pacati Drepani dictus Teodosio; Rutilio Namaciano, De reditu suo; y Claudio Claudiano, De consulatu Stilichonis. En aquellos casos en que disponemos de traducción castellana, la hemos seguido. Para la traducción de la Historia Augusta hemos consultado la traducción de editorial Akal, Picón, Vicente y CASCón, Antonio (editores), Historia Augusta (Madrid, 1989). En donde no disponíamos de una traducción de calidad hemos intentado proporcionar una versión castellana lo más cercana posible al texto original.

${ }^{17}$ El texto que comentamos ha sido estudiado, desde la publicación del Papiro de Giessen, por autores procedentes de todos los idiomas. Solo para nuestro estudio hemos escogido los siguientes trabajos: BANCALARI, Alejandro, La "civitas" romana en Livio Druso y Caracalla: aspectos de sus proyectos y realizaciones, en Tiempo y Espacio 7-8 (1997-1998), pp. 77-89; EL Mismo, La "Constitutio Antoniniana": aproximaciones, significado y características, en Semanas de Estudios Romanos (1998), IX, pp. 57-67; El Mismo, Relación entre la "Constitutio Antoniniana” y la "Imitatio Alexandri" de Caracalla, en Revista de Estudios Histórico-Jurídicos 22 (2000), pp. 17-29; El Mismo, Coexistencia o enfrentamiento entre el Derecho romano y los derechos locales 
la famosísima obra de Caracalla, una constitución imperial dictada con el objeto de conceder la ciudadanía romana a todos los habitantes libres del imperio.

Se ha usado la totalidad de las obras bibliográficas en forma de monografías disponibles en nuestro medio, más las que se pueden obtener de bases de datos electrónicas. Han tenido especial importancia los textos que estudian el tema de la ciudadanía y la romanización. Por su valor orientador se ha recurrido a obras clásicas provenientes de la historiografía europea desde mediados del siglo XIX y hasta inicios del siglo XXI.

Se han empleado también obras sinópticas y de divulgación cuando ellas resultaban directamente relacionadas con la materia tratada. Dada la realidad de los fondos bibliográficos a nuestro alcance, la mayor parte de estas obras se encuentra redactada en español. Un número apreciable en italiano, inglés o en francés. Los esquemas de exposición sobre los efectos culturales de la ampliación de la ciudadanía en el Imperio los hemos diseñado siguiendo de cerca dos modelos precisamente escogidos por su carácter omnicomprensivo del fenómeno ciudadano, aunque la primera de ellas, obra de la profesora Florence Dupont ${ }^{18}$ se refiere al periodo Republicano y no al principado como nuestro estudio y la otra, obra del profesor Fernando Díaz Plaja ${ }^{19}$, trata de la ciudadanía y la vida romana especialmente para el contexto social de Hispania.

Las fuentes histórico-jurídicas se han usado en la medida en que aportan un enfoque particular o diverso o más acucioso que la historiografía clásica. Sin embargo, los estudios histórico-jurídicos sobre nuestra materia son realmente escasos y las más de las veces se descubre que repiten los conceptos abordados por los demás ${ }^{20}$. Las obras de Derecho romano siguen el clásico modelo de expli-

de las provincias, en Revista de Estudios Histórico-Jurídicos 26 (2004). En el ámbito de los estudios jurídico-romanistas no podemos omitir la obra clásica del profesor Álvaro d'Ors, su tesis doctoral; véase: D’Ors, Álvaro, “Constitutio Antoniniana” (P. Giss. 40, I). Contribución al estudio de su valor y significado para la historia del Derecho Romano (Madrid, 1941); y la tesis doctoral de WolfF, Hartmut, Die "Constitutio Antoniniana” und Papyrus Gissensis 40.I. (Colonia, 1975). El relativo silencio que, sobre el documento indicado, mantienen las obras de la historiografía jurídica ha sido llenado gracias a los historiadores clásicos. Entre éstos últimos destaca la figura del profesor Alejandro Bancalari con los trabajos de investigación ya citados. Asimismo, entre otros autores, hemos considerado oportuno el contar con el respaldo de la historiografía anglosajona, de la cual destacamos tres estudios ya clásicos: Lawton Sherman, Charles, The "Constitutio Antoniniana" in the Light of the "Gnomon tou Idiou Logou", en Transactions and Proceedings of the American Philological Association 59 (1928), pp. 33-47, Jones, A. H. M., Another Interpretation of the "Constitutio Antoniniana", en The Journal of Roman Studies 26 (1936) 2, pp. 223-235, Benario, Herbert W., The "Dediticii" of the "Constitutio Antoniniana", en Transactions and Proceedings of the American Philological Association 85 (1954), pp. 188-196.

${ }^{18}$ Véase: Dupont, Florence, El Ciudadano romano, durante la República (Buenos Aires, 1992).

${ }^{19}$ Véase: Díaz-Plaja, Fernando, La vida cotidiana en La España Romana (Madrid, 1995).

${ }^{20}$ Hemos tenido a la vista las obras de Coronas González, Santos M., Manual de Historia del Derecho español (Valencia, 1996); Sánchez-Arcilla Bernal, José, Historia del Derecho español (Zaragoza, 2001); El Mismo, Historia del Derecho. Instituciones politico-administrativas (Madrid, 1995), I; BARRIENTOS GRANDÓN, Javier, Introducción a la Historia del Derecho chileno. 
cación de la ciudadanía que contienen las Institutiones de Gayo. Las monografías específicamente dedicadas a la ciudadanía son también escasas.

Se constata asimismo una curiosa tendencia a desarrollar los aspectos jurídicos formales del proceso de acceso a la latinidad y a la ciudadanía ${ }^{21}$, pero sin realizar la crítica de las fuentes o de la labor realizada por los autores más antiguos.

Estas limitaciones de la bibliografía histórico-jurídica se han visto, en parte, salvadas por una nutrida cantidad de estudios historiográficos provenientes de autores del ámbito de la historia clásica e incluso del campo de la filología helenística.

En relación con la bibliografía proveniente de revistas especializadas, encontramos una riquísima fuente de información y referencias. Logramos tener acceso a un total de treinta y cinco Revistas especializadas en Historia Jurídica, Historia Clásica e Historia General. De ellas catorce están redactadas en español (seis provenientes de Chile), tres en francés, una en italiano, dieciséis en inglés, y una en varios idiomas. Ellas nos proporcionaron un total de 43 ensayos y artículos sobre nuestro tema, material de gran importancia pues recoge desde estudios prosopográficos hasta análisis filológico-epigráficos, que permiten formarse una imagen muy completa de la cultura romana en la época del término del Principado.

ii) De las revistas consultadas, fueron especialmente importantes las relativas a la ciudadanía desde un punto de vista cultural, la expansión de la ciudadanía en Hispania y occidente en general, la descripción de los hábitos y costumbres romanas en las ciudades occidentales del Imperio, incluyendo las tradiciones y testimonios epigráficos y la representación pública de los principales hechos de sus élites sociales.

iii) Otro grupo significativo se dedica al análisis de la Constitutio Antoniniana, documento que desde su descubrimiento en 1910 ha motivado la producción de ingentes cantidades de material especializado, al que hemos tenido acceso en versión impresa o electrónica. Se consultaron siete fuentes electrónicas, particularmente para recoger literatura de origen estadounidense ${ }^{22}$.

Derechos Propios y Derecho Común en Castilla (Santiago, 1994), I; AzCÁrraga, Joaquín de Pérez-Prendes Muñoz de Arraco, José Manuel, Lecciones de Historia del Derecho español (3a edición, Madrid, 1997); Valdeavellano, Luis G. de, Curso de Historia de las Instituciones españolas, de los orígenes al final de la Edad media (3a edición, Salamanca, 1992); ERrÁZURIZ Eguiguren, Maximiano, Historia externa de Roma, del acto jurídico, de las personas (2a edición, Santiago, 1989) I; Salvat Monguillot, Manuel, Breve Historia del estudio del Derecho (Santiago, 2001); Alvarado Planas, Javier - Montes Salguero - Jorge, Pérez Marcos, Regina - Sánchez González, María Dolores, Manual de Historia del Derecho y de las instituciones (Madrid, 2006); y la obra del profesor José Antonio Escudero, el único de los historiadores del Derecho que introduce el análisis crítico de la literatura histórico-jurídica disponible, véase: Escudero, José Antonio, Curso de Historia del Derecho. Fuentes e instituciones políticoadministrativas ( $2^{\text {a }}$ edición, Madrid, 1995).

${ }^{21}$ Una notable excepción por su manejo directo de fuentes primarias y un enfoque jurídico original, es la obra del profesor Barrientos Grandón, quien estudia especialmente la evolución jurídica de la condición ciudadana desde antes de los Flavios y hasta después de la Constitutio Antoniniana de 212. Véase: Barrientos Grandón, Javier, Curso de Historia del Derecho (Santiago, 2003), I.

${ }^{22}$ Una importante cantidad de estudios sobre el tema ha sido extraída de la base de datos Jstor. Véase: http://www.jstor.org (12-02-2009). 
Una observación final sobre lo que hemos constatado en esta investigación. El estudio de la nutrida bibliografía que hemos consignado en estas líneas demuestra que mientras el siglo XIX destacó por los estudios epigráficos, en el siglo XX e inicios del XXI, la gran cantera de testimonios del pasado romano está constituida por el estudio y análisis paleográfico y filológico de los papiros, de los cuales, el más destacado para nuestro estudio es el Papiro de Giessen.

Esperamos que el presente trabajo logre motivar interés por re-estudiar el tema de la ciudadanía romana más allá de sus componentes jurídicos, pues se trata en verdad de un tema de capital importancia para comprender a la cultura a la que tanto debemos. Asimismo cabe formular votos porque la historiografía jurídica pueda aportar nuevos enfoques y análisis críticos en un tema que por largos años ha estado ajeno a la labor de sus investigadores.

\section{LOS EMPERADORES ROMANOS DE CARTAGO}

\section{Origen de los Severos ${ }^{23}$.}

La familia del primer emperador Severo, Lucio Septimio pertenecía al orden ecuestre. Podemos formular ciertos paralelos con los Flavios debido a este origen similar. Dos de los tíos de Septimio habían accedido a la dignidad consular y otro de sus parientes, del mismo nombre que el futuro emperador, había sido cónsul en dos oportunidades y fue su mentor en la carrera política. De igual manera los Flavios habían ido escalando poco a poco los peldaños del cursus honorum hasta llegar a Vespasiano, quien, por su carácter y aptitudes militares tenía mucho en común con Lucio Septimio Severo. Ambos profundamente romanos, aunque ninguno aristócrata y en el caso del último, de precarios ancestros latinos.

Sobre estos orígenes nos dice Elio Esparciano: "Interfecto Didio Iuliano Severus Africa oriundus imperium obtinuit. Cui civitas Lepti, pater Geta, maiores equites Romani ante civitatem omnibus datam; mater Fulvia Pia, patrui magni Aper et Severus consulares, avus paternus Macer, maternus Fulvius Pius fuere ${ }^{214}$.

El lugar de origen del emperador, la ciudad de Leptis Magna, fue engrandecido bajo su reinado, se le dotó de nuevos templos, termas, foros y monumentos ${ }^{25}$. Severo quería de esta forma dar a entender que era un romano tanto por cul-

\footnotetext{
${ }^{23}$ Para el estudio de los Severos, véase: Grant, Michel, The Severans: The Changed Roman Empire (New York, 1996); CALDERINI, Aristide, I Severi. La crisi dell'Impero nel III secolo (Bolonia, 1949); también de Blásquez Martínez, José María, Leptis Magna. Patria de Septimio Severo en Revista de Arqueología 250 (2001), pp. 32-43, hay versión digital electrónica a disposición para ser consultada en el sitio web del Gabinete de Antigüedades de la Real Academia de la Historia http://descargas.cervantesvirtual.com/servlet/SirveObras/02580625333584673432268/031861.pdf?incr=1 (13-03-2009).

${ }^{24}$ Elio Esparciano, Historia Augusta, X,1-3: "Después del asesinato de Didio Juliano, alcanzó el poder imperial Severo, que era oriundo de África. Su ciudad natal fue Leptis, su padre fue Geta y sus antepasados fueron caballeros romanos, antes de que hubiera sido otorgada a todos la ciudadanía; su madre fue Fulvia Pía; sus tíos paternos fueron Apro y Severo, los dos consulares; su abuelo materno fue Macro y su abuelo paterno Fulvio Pío".

${ }^{25}$ Como el Septizodium, o puerta ceremonial junto al Palatino, construcción ordenada por Septimio.
} 
tura como por sus orígenes. Al respecto, el César había visto cómo su primera mujer Pacca Marciana, originaria como él de Leptis Magna, era rechazada por los círculos aristocráticos y senatoriales de la Urbe debido a su mal manejo del latín, el que hablaba con fuerte acento africano. Ya mayor, Severo contrajo un segundo matrimonio con una noble de origen sirio, Julia Domna, por lo que en su descendencia, la sangre romana se volvió aún más débil.

\section{Breve sintesis de los aspectos más destacados de la dinastía severiana ${ }^{26}$.}

El balance del gobierno de la dinastía resulta contradictorio. Las grandes dotes de estadistas de Lucio Septimio y de Alejandro Severo, se vieron eclipsadas por la demencia megalómana de Caracalla y el furor depravado de Heliogábalo.

a) Lucio Septimio ${ }^{27}$ nació en Leptis Magna (Tripolitania), ciudad cercana a la colonia romana de Cartago, en África el 11 de abril de 146, hijo de Publio Septimio Geta. Su familia le proporcionó buenos estudios literarios, en los que destacó prontamente. A los 26 años Severo viajó a Roma en donde obtuvo el cargo de Cuestor de Cerdeña. Desempeñó cargos como legado del procónsul de África, tribuno de la plebe, cuestor y legado jurídico del gobernador de la Tarraconensis. Tras estos inicios se desempeñó en cargos militares, en los que destacó todavía más. Entre 189 y 192 sirvió el consulado. Tras el asesinato de Cómodo y la defenestración y muerte de Pértinax, sus legiones lo proclamaron emperador. Era el mes de abril de 193. Tras la aclamación de sus hombres debió enfrentarse con sus competidores por el trono, Didio Juliano, Pescenio Níger y Clodio Albino.

Ordenó el licenciamiento de los pretorianos que se habían visto involucrados en la lucha por el poder y en las muertes de sus antecesores en el poder. Vencidos sus oponentes en el 197, tras casi 4 años de continuas luchas civiles, tuvo que acudir al Oriente a fin de sofocar una ofensiva de los partos. Vencidos en el mismo año, Severo se apoderó de Ctesifonte, del tesoro persa y de más de 100.000 prisioneros que fueron llevados a Roma como esclavos ${ }^{28}$. Entró en la urbe en 202 siendo aclamado por todos.

Reformó el Senado. De conformidad al ideario político que sería continuado por sus sucesores, Severo aumentó el número de provinciales, específicamente el de orientales y africanos en la vieja cámara ${ }^{29}$.

El mismo Senado ordenó erigir en su honor un arco del triunfo que aún hoy

${ }^{26}$ Véase: SCARre, Chris, Chronicle of the Roman Emperors, The Reign-By-Reign Record of the Rulers of Imperial Rome (London, 1997), pp. 130 ss.

${ }^{27}$ Véase: Birley, Anthony R., Septimius Severus, the African Emperor (2a edición, Londres, 1999). Hay versión electrónica disponible en http://books.google.cl/books?id= Obu1zSDuUYsC\&dq=BIRLEY,+A., +Septimius + Severus, + the+African+Emperor\&pri ntsec $=$ frontcover\&source $=$ bn $\&$ hl $=$ es $\&$ ei $=3 \mathrm{pXsSe6MIYWjtgef69HEBQ \& sa}=X \&$ oi $=$ bo ok_result\&ct=result\&resnum $=4$ (20-04-2009).

${ }^{28}$ Véase: Mommsen, Theodor, El mundo de los Césares (2a edición, 1941, trad. cast. México, 2006), p. 301.

${ }^{29} \mathrm{Al}$ respecto, sostiene Piganiol, André, Historia de Roma (1939, trad. cast. Buenos Aires, 1981), p. 375: "El ultraje hecho al Senado se hacía también a Italia. La proporción de senadores italianos disminuyó en provecho de los provincianos, sobre todo de los orientales. Los italianos fueron excluidos del pretorio; dejaron de tener el privilegio de suministrar centuriones". 
se conserva. En 208 volvió a partir en campaña hacia Britania, en donde se había producido una rebelión de las legiones. Lo acompañaron sus hijos Geta y Caracalla. Este último promovió un alzamiento en contra de Severo, quien murió en Eboracum (York) el 4 de febrero de 211. Sus restos fueron llevados a Roma donde el Senado le otorgó la apoteosis. Contrajo matrimonio con una noble de origen sirio, llamada Julia Domna, quien le dio dos hijos, Basiano, llamado Caracalla y Geta. Ambos heredarían el trono conjuntamente según la voluntad de su padre, aunque el primero no tardaría en hacer asesinar al otro.

El gobierno del primer Severo marcó la pauta de lo que serían sus sucesores. Dotado de innegables virtudes de estadista, dotó al imperio de grandes obras de adelanto, reformó los edificios públicos de Roma, partiendo por las construcciones Imperiales en el Palatino, reformó la administración, volviendo a los principios de honestidad y de servicio público de la época de los Antoninos ${ }^{30}$, aunque usó de la política de centralizarla en pocos ministros y colaboradores ${ }^{31}$, concedió abundantemente la ciudadanía romana a numerosas poblaciones provinciales, entre las cuales se contaron los habitantes de su natal Leptis Magna, saneó las finanzas imperiales y dejó los graneros de Roma llenos ${ }^{32}$, asegurando la dotación de alimentos por años, pero en su incesante actividad militar, enfrentado casi siempre a numerosos enemigos, invasiones y rebeliones, se apoyó excesivamente en el ejército ${ }^{33}$, habiendo descuidado otros de los acuciantes problemas que apremiaban al Imperio. La leyenda que asegura que su última voluntad fue "Mantened al ejército y olvidaos de lo demás" es un claro ejemplo de lo que indicamos ${ }^{34}$.

Como ya hemos dicho, la sucesión de Severo no resultó como había planificado

\footnotetext{
${ }^{30}$ Sobre las actuaciones de los Severos en general y las de Septimio en particular, en orden a adoptar el legado de los Antoninos y emular sus obras urbanísticas, como forma de legitimarse en el trono, véase: Fernández Ardanaz, Santiago - GonzÁlez Fernández, Rafael, El "consensus" y la "auctoritas" en el acceso al poder del emperador Septimio Severo, en Antigüedad y cristianismo 23 (2006), pp. 23-37. Hay versión electrónica disponible en http://interclassica.um.es/investigacion/hemeroteca/antigueedad_y_cristianismo/numero_23_2006/ el_consensus_y_la_auctoritas_en_el_acceso_al_poder_del_emperador_septimio_severo (05-02-2009).

${ }^{31}$ Preparaba de este modo la centralización que vendrá definitivamente con Diocleciano a fines del siglo III. Uno de esos colaboradores, prefecto del Pretorio, sería nada menos que Ulpiano, el famoso jurista.

${ }^{32}$ Herodiano, Historia del Imperio romano después de Marco Aurelio, III,15,3, emite un juicio muy favorable a Severo al afirmar que después de un reinado de 18 años dejaba un imperio caracterizado por una hacienda pública más próspera que nunca y un ejército invencible.

${ }^{33}$ Véase: Piganiol, André, cit. (n. 29), p. 376.

${ }^{34}$ Elio Esparciano, Historia Augusta, X, 23, ofrece, sin embargo, una versión distinta de los últimos momentos de Severo: "Turbatam rem publicam ubique accepi, pacatam etiam Britannis relinquo, senex et pedibus aeger frrmum imperium Antoninis meis relinquens, si boni erunt, imbecillum, si mali" ("Recibí un estado alborotado por todas las partes y lo dejé en paz incluso con la Bretaña, entregando a mis Antoninos, a pesar de mi vejez y de la gota que me acosa, un imperio sólido, si ellos actúan adecuadamente, pero muy débil, si gobiernan mal”). Sobre los aspectos más propiamente militares del reinado de Severo, véase: KAGAN, Kimberly, Redefining Roman Grand Strategy, en The Journal of Military History 70 (2006) 2, pp. 333-362. Hay versión electrónica disponible en http://www.jstor.org/stable/4137956 (23-03-2009).
} 
el Emperador. Los dos herederos se odiaban mutuamente. Pronto se hizo evidente que no podrían cogobernar, por lo que una salida violenta era la más esperable.

b) Caracalla ${ }^{35}$ dio pronto señales de que la época de su padre había terminado. Una personalidad megalómana que se manifestaría en toda su intensidad a partir de su subida al trono, le ha llevado a ser considerado uno de los más déspotas de los emperadores romanos. Aunque, una valoración más objetiva del gobierno de este Severo no puede omitir algunos elementos interesantes, dentro de los cuales se encuentra, por cierto, la Constitutio Antoniniana. De la misma manera hemos de mirar con cuidado a la figura de su hermano Geta, asesinado por orden de Caracalla, que tradicionalmente se ha adornado con las virtudes del mártir, aunque sin que podamos probar que ellas correspondían a la realidad ${ }^{36}$.

Los escritores de la época como Herodiano, Dión Casio y Elio Esparciano, nos han dejado una clara idea de la imagen que proyectó el heredero de Septimio Severo. Una imagen casi unánimemente negativa ${ }^{37}$.

Las obras del nuevo emperador se ven teñidas siempre por sus numerosos

${ }^{35}$ César Marco Aurelio Severo Antonino Pío Augusto, gobernó durante 7 años, desde 211 a 217. Debe su sobrenombre a una capa de color rojo y bordados plateados que usaba a la manera de los germanos. Véase: Herodiano, Historia del Imperio Romano después de Marco Aurelio, IV,7,4.

${ }^{36}$ Nuestras fuentes sobre la personalidad de Geta provienen fundamentalmente de Herodiano, Dión Casio y Elio Esparciano. Éste último lo describe así (Elıo Esparciano, Historia Augusta, XIV,4,2 y 5,2): "Fuit adulescens decorus, moribus asperis, sed non impius, amorum tractator, gulosus, cupidus ciborum et vini varie conditi [...]. Fuit in litteris adsequendis tenax veterum scriptorum, paternarum etiam sententiarum memor, fratri semper invisus, matri amabilior quam frater, subbalbe tamen canorus. vestitus nitidi cupidissimus [...]" ("Fue un joven elegante, de carácter rudo, pero no impío, avaro, aficionado a los juegos de palabras, goloso, glotón y amante de vinos de distinta solera [...]. Fue tenaz en el aprendizaje de las obras de los antiguos escritores y recordaba también las ideas que su padre le había inculcado [...] y poseía una voz melodiosa, aunque algo balbuceante. Le gustaban muchísimo los vestidos elegantes [...]"). No parece una descripción particularmente brillante, salvo para dejar en claro que su carácter distaba de la violencia que caracterizaba a su hermano mayor.

${ }^{37}$ Herodiano, Historia del Imperio Romano después de Marco Aurelio, IV, 6, 1-4, lo describe como un asesino y megalómano, que no dejó por mandar a matar desde su propio hermano hasta los senadores más dignos, los niños más pequeños. Todos los que en su momento manifestaron simpatías por Geta morirían de las maneras más crueles imaginables. Los eliminados iban desde atletas, aurigas del circo, aristócratas, la anciana princesa Cornificia, hija de Marco Aurelio, las sacerdotisas de Vesta, acusadas de violar su castidad e incluso la muchedumbre que había cometido la falta de abuchear a un auriga del gusto del emperador. Por su parte, Elio Esparciano, Historia Augusta, XIII,11,5, lo retrata en términos igualmente duros. Al comentar su divinización por parte de su propio asesino, el usurpador Macrino, señala: "Hic tamen omnium durissimus et, ut uno complectamur verbo, parricida et incestus, patris, matris, fratris inimicus, a Macrino, qui eum occiderat, timore militum et maxime praetorianorum inter deos relatus est" " $S$ in embargo, este individuo, el más cruel de todo los hombres, y, para expresarlo con una sola frase, fratricida, incestuoso y enemigo de su padre, de su madre y de su hermano, fue elevado a la categoría de dios por su asesino Macrino, por temor a los soldados y, sobre todo, a los pretorianos"). Finalmente Dión CASIO, Historia de Roma, LXXVIII,6,1, nos lo describe como un hombre que pertenecía a tres razas, poseedor de ninguna de su virtudes y de todos sus vicios, la debilidad, la cobardía y la temeridad de sus antepasados galos, la rudeza y crueldad de los africanos y la astucia siria de su lado materno. 
crímenes. Se ha afirmado que hasta 20.000 personas fueron muertas por considerárselas partidarias de $\mathrm{Geta}^{38}$. Caracalla se hundiría rápidamente en los delirios de su propia mente, asumiría una actitud obsesiva con la imagen de Alejandro el Grande, a quien imitaría en sus vestiduras y campañas militares en oriente ${ }^{39}$. Es en el aspecto militar en donde se pueden contar los aspectos más rescatables de su gobierno. Varias guerras contra los germanos le fueron favorables y una campaña contra los partos resultó exitosa para el emperador debido a un conflicto civil interno entre sus enemigos.

Los principales aspectos civiles de su gobierno se relacionan con la elevada cultura jurídica desarrollada por Papiniano, Ulpiano y Paulo ${ }^{40}$, la construcción de las magníficas termas que hizo construir a la vera del Palatino, la creación de una nueva unidad monetaria, el antoniniano ${ }^{41}$ y la dictación de la Constitutio Antoniniana.

Como decimos más adelante, las referencias a la Constitutio de 212 son relativamente escasas en las fuentes de la época ${ }^{42}$. Sólo Dión Casio alude a ella para criticar los motivos de Caracalla con su dictación.

Caracalla vería el fin de sus días en medio de una nueva campaña contra los partos. El Prefecto del Pretorio Macrino, en connivencia con los pretorianos, planificó el magnicidio, que tuvo lugar el 8 de abril de 217. Con ello se ponía fin al despótico reinado del hijo de Severo y se abría un breve paréntesis con el mismo Macrino y su hijo Diadumeno como protagonistas del poder imperial.

${ }^{38}$ Uno de los crímenes más famosos de Caracalla es el que dice relación con la muerte de Papiniano, el más importante de los jurisconsultos romanos y Prefecto del Pretorio al inicio del gobierno de Caracalla. La causa de su asesinato se relaciona directamente con la cercanía de Papiniano con Geta. Tras la muerte de éste último, Papiniano no guardó silencio, y ello motivó la airada reacción de Caracalla, quien ordenó su muerte. Una relación detallada de esta muerte se encuentra en Elio Esparciano, Historia Augusta, XIII, 8,1-10.

${ }^{39}$ Este aspecto de la personalidad de Caracalla ha sido tratado por BANCALARI, Alejandro, Relación, cit. (n. 17), pp. 17-29

${ }^{40}$ Dicha cultura jurídica se centraba en la protección de los más débiles frente a los poderosos, era una forma muy original y en cierto sentido revolucionaria, de atacar las diferencias sociales aún vigentes entre los ciudadanos. Al respecto, DAWSON, Christopher, cit. (n. 1), p. 93, sostiene que en la mente de estos juristas está plenamente vigente el ideal de Marco Aurelio: "el ideal de una comunidad en la cual la ley es igual para todos, una comunidad administrada con debido respeto a derechos iguales y a igual libertad de palabra, y el ideal de un gobierno de majestad real que respeta más que todo la libertad de los gobernados. Este mismo ideal inspiró a los grandes juristas del siglo siguiente, tales como Ulpiano y Papiniano, con quienes los principios humanistas e ilustrados del periodo de los Antoninos fueron incorporados en las tradiciones de la legislación romana”.

${ }^{41}$ Moneda de plata creada con el fin de hacer frente a los extraordinarios gastos militares impulsados por Caracalla, especialmente sus campañas al Oriente. Importaba una devaluación de hecho de un 50\% del denario. Véase: García Moreno, Luis A., La Antigüedad clásica. El Imperio Romano (Pamplona, 1989), II, p. 279 s.

${ }^{42}$ Herodiano y la Elio Esparciano la omiten del todo. El primero afirma que luego de sus crímenes, Caracalla partió en viaje por las provincias, en lo que se cree que es una intencionada laguna de las actuaciones jurídicas del emperador. Véase: Herodiano, Historia del Imperio Romano después de Marco Aurelio, IV,7,1. 
c) Macrino ${ }^{43}$, cuyos orígenes resultan relativamente oscuros, había ido escalando paso a paso todos los peldaños del cursus honorum, hasta llegar a ser nombrado Prefecto del Pretorio. Su reinado sería, empero, muy breve. Aunque algunas de nuestras fuentes suponen que la muerte de Caracalla se decidió cuando ya se tenía certeza de que Macrino sería elevado al trono, su aclamación como emperador tuvo lugar 3 días después de la muerte de aquél, el 11 de abril de 217 .

Proveniente del orden ecuestre provincial, de formación jurídica ${ }^{44}$, Macrino había alcanzado las altas esferas de la administración en tiempos de Septimio Severo.

Decidido a acabar con la guerra en Oriente, Macrino aceptó sobornar a los partos con la enorme suma de 200 millones de sestercios. Esta decisión se estimó como una humillación entre los soldados del ejército, entre quienes Caracalla había sido muy popular. Asimismo, cometió el error de eliminar varios de los privilegios concedidos al ejército por su antecesor. Sumando esta circunstancia a la aparición de un supuesto hijo ilegítimo de Caracalla, Vario Avito, más tarde llamado Heliogábalo, la posición de Macrino se hizo insostenible. Intentó legitimarse proclamando César a su pequeño hijo Diadumeno. Ambos serían ejecutados en junio de $218^{45}$.

d) Las maniobras de las mujeres de la dinastía severiana llevarían al poder al sobrino de Caracalla, Heliogábalo, hijo de una sobrina de Julia Domna, la madre de Caracalla. El nuevo césar contaba con escasos 14 años cuando fue proclamado emperador el 15 de mayo de $218^{46}$. Su breve reinado estuvo dominado por sus delirios religiosos, las maquinaciones de su madre Soemia y su abuela Julia Mesa. Ésta última confió el gobierno a un liberto, Comazón Eutiquiano. Las locuras de heliogábalo, entregado por completo a la religión de Baal, el culto del sol, al cual hizo construir templos en la propia Roma, rápidamente forjaron una oposición al nuevo régimen entre los círculos senatoriales y tradicionalistas de la sociedad aristocrática $^{47}$. Julia Mesa se percató a tiempo de esta circunstancia, por lo que

${ }^{43}$ Marco Opilio Severo Macrino Augusto (164-217-218), nacido en Cesarea de Mauritania, no tiene relación de parentesco con los Severo, pese a su origen africano, seguramente de familia mauritana romanizada, aunque para disimular su ilegal ascensión al trono, especialmente respecto de los soldados, adoptó el nomen gentilicio de los Severo. Véase: Dión Casıo, Historia de Roma, LXXIX,11.

${ }^{44}$ La Historia Augusta, XV,13,1, indica que Macrino ordenó dejar sin efectos los rescriptos imperiales como fuente de derecho, fundándose en que la mera voluntad de un emperador ignorante no podía ser la base de una decisión jurídica.

${ }^{45}$ Véase: Scarre, Chris, cit. (n. 26), pp. 146 s.; y Julio Capitolino, Historia Augusta, XV,10,4, Elio Lampridio, Historia Augusta, XVI,8,2 y XVI,9,4.

${ }^{46}$ Se afirmaba en sordina que el nuevo emperador era hijo ilegítimo del propio Caracalla.

${ }^{47}$ Elio Lampridio, Historia Augusta, XVII,20,1-3, nos ha dejado una descripción de su actitud respecto del Senado y de la poderosa clase de los ciudadanos de orden ecuestre: "Senatum nonnumquam ita contempsit, ut mancipia togata appellaret, populum Romanum unius fundi cultorem, equestrem ordinem in nullo loco habens. praefectum urbicum saepe post cenam ad potandum vocabat adhibitis et praefectis praetorio, ita ut, si recusarent, magistri officiorum eos cogerent. voluit et per singulas urbis regionespraefectos urbi facere, ut essent in urbe quattuordecim. et fecisset, si vixisset, promoturus omnes turpissimos et ultimae professionis homines" ("A veces 
hizo que su nieto adoptara como heredero a su primo hermano Alexiano, llamado Alejandro Severo. Éste era hijo de Julia Mammea, hija a su vez de Julia Mesa.

No obstante estos intentos de remedios, malas cosechas, amenazas de hambrunas y la crisis económica quitaron a Heliogábalo la poca popularidad que le restaba, con lo que fue asesinado por un motín de los pretorianos el 12 de marzo de 222, junto con su madre ${ }^{48}$. En el mismo día Alejandro Severo era proclamado emperador y se daba inicio al último de los reinados de la dinastía iniciada por Septimio Severo en 198.

e) El reinado de Alejandro ${ }^{49}$ principió bajo la égida de su madre Julia Mamea y su abuela, Julia Mesa. En esos primeros años destacó la figura del nuevo Prefecto del Pretorio, Domicio Ulpiano, el famoso jurisconsulto ${ }^{50}$. Desaparecido éste por un sublevación de los pretorianos que le asesinaron, el gobierno quedó en manos cada vez más, de los círculos militares. Se trata de una profundización de una política que se había desarrollado en ciernes, como hemos dicho, ya en los tiempos del primero de los Severos, Septimio.

Alejandro promovió una reforma agraria para beneficiar a los pequeños propietarios y una promoción de los soldados para transformarlos en terratenientes. Igualmente impulsó ciertas reformas legislativas para conferir derechos a los esclavos. Confirió nuevos beneficios y privilegios a los comerciantes y artesanos. Con ello consolidaba la base social de su gobierno y se volvía cada vez más popular entre los grupos medios de la sociedad imperial, era la antigua política de promoción de los caballeros y decuriones que había iniciado Septimio y continuado incluso Caracalla. En su comportamiento personal igualmente evidenció este carácter de gobernante ciudadano ${ }^{51}$. Incluso manifestó tolerancia por la secta cristiana, con lo

despreció al Senado hasta tal punto, que llamaba a los senadores esclavos togados y al pueblo romano labrador de una sola propiedad, no observando ninguna consideración hacia el orden ecuestre. Invitaba con mucha frecuencia al prefecto de la Ciudad a beber un trago juntos después de comer, invitación que cursaba también a los prefectos del Pretorio de tal forma que, si la rehusaban, los obligaban a aceptarla los jefes de las chancillerías. Tuvo también la intención de nombrar un prefecto por cada uno de los distritos de la Ciudad para que hubiera catorce en Roma. Y hubiera llevado a cabo su propósito, si hubiera vivido, para promocionar a los hombres más degenerados y de las más bajas profesiones sin excepción”). En esta descripción se manifiesta el estupor que motivó en los historiadores posteriores esta falta de consideración por los ciudadanos, que parecía ser una constante en Heliogábalo.

${ }^{48}$ Véase: Herodiano, Historia del Imperio Romano después de Marco Aurelio, V, 8, 8-10.

${ }^{49}$ César Marco Aurelio Severo Alejandro Pío Felix Augusto (208-222-235), su reinado ha sido uno de los más estudiados por la historiografía romanista en el siglo XX. Las fuentes de la época han dejado un retrato de Alejandro favorable a su persona. Dión Casio y Herodiano le consideran un digno heredero de Septimio Severo y la Historia Augusta traza respecto de él la descripción de un príncipe ejemplar, poseedor de todos los atributos del genio y la virtud. Existe aquí una controversia sobre los propósitos de tales descripciones. Véase: García MoRENO, Luis A., La Antigüedad, cit. (n. 41), p. 272. Asimismo, véase la obra clásica de JARDÉ A., Etudes critiques sur la vie et le règne de Sévère Alexandre (Paris, 1925).

${ }^{50}$ Igualmente destacado sería Julio Paulo, véase: Herodiano, Historia del Imperio Romano después de Marco Aurelio, VI,1,4.

${ }^{51}$ Elio Lampridio, Historia Augusta, XVIII,4,1: "Dominum se appellari vetuit. epistulas ad se quasi ad privatum scribi iussit servato tantum nomine imperatoris. gemmas de calciamentis et vestibus tulit, quibus usus fuerat Heliogabalus. veste, ut et pingitur, alba usus est nec aurata, 
que se ponía en evidencia una nueva actitud de los gobernantes romanos respecto de un culto que solo había concitado desprecio y persecución en el pasado ${ }^{52}$.

$\mathrm{Su}$ respeto por las instituciones del gobierno principesco, se denota en gestos de hondo significado jurídico, como la concesión de la senaturía a los Prefectos del Pretorio a fin de evitar que los senadores fueran juzgados por individuos de un orden social inferior: "Praefectis praetorii suis senatoriam addidit dignitatem, ut Viri Clarissimi et essent et dicerentur. quod antea vel raro fuerat vel omnino diu non fuerat, eo usque ut si quis imperatorum successorem praefecto praetorii dare vellet, laticlaviam eidem per libertum summitteret, ut in multorum vita Marius Maximus dixit. Alexander autem idcirco senatores esse voluit praefectos praetorii, ne quis non senator de Romano senatore iudicaret" ${ }^{\prime 3}$ A ello se une su preocupación por la restauración de las grandes construcciones de sus predecesores en el trono. Había aquí, según Lampridio, un deseo de ser reconocido plenamente como romano ${ }^{54}$.

paenulis togisque communibus" "Prohibió que le llamaran señor. Ordenó que le escribieran las cartas como si fuera un simple particular y que mantuvieran solamente el título de emperador. Eliminó de los calzados y de los vestidos imperiales las piedras preciosas que había utilizado Heliogábalo. Utilizaba un vestido blanco sin adornos de oro, tal como aparece en sus retratos, y pénulas y togas normales"). El mismo Lampridio, Historia Augusta, XVIII,11,4, nos refiere que Alejandro, en una comparecencia ante el Senado rechazó el título de "Magno" con que los senadores deseaban honrarle, indicando que se sentiría más honrado si le consideraban uno de ellos. En el igual sentido se puede citar este pasaje de la misma Historia Augusta, XVII,18,1-2: "Salutabatur autem nomine, hoc est "Ave, Alexander." si quis caput flexisset aut blandius aliquid dixisset, ut adulator, vel adiciebatur, si loci eius qualitas pateretur, vel ridebatur ingenti cachino, si eius dignitas graviori subiacere non posset iniuriae. salutatus consessum obtulit omnibus senatoribus atque adeo nisi honestos et bonae famae homines ad salutationem non admisit, iussitque - quemadmodum in Eleusinis sacris dicitur, ut nemo ingrediatur nisi qui se innocentem novit - per praeconem edici, ut nemo salutaret principem, qui se furem esse nosset, ne aliquando detectus capitali supplicio subderetur" "“Se le saludaba diciendo solamente el nombre, por ejemplo: "Salud, Alejandro". Si alguien en alguna ocasión había inclinado la cabeza o había hecho un comentario excesivamente lisonjero, o bien Alejandro le hacía alejar de su presencia como adulador, si la índole de su clase social lo permitía, o bien se reía a grandes carcajadas de él, si la dignidad que ostentaba no admitía la posibilidad de verse sometida a una injuria tan grave. Ofreció asiento a todos los senadores cuando venían a saludarle, pero sólo admitió a la salutación a aquellos ciudadanos que eran honorables y tenían buena fama y ordenó que se proclamara por medio de un pregonero (de la misma manera que se proclama durante la celebración de los misterios Eleusinos que nadie entre a participar en ellos, salvo quien se considere inocente) que nadie que se reconociera ladrón acudiera a visitar al príncipe, para no verse expuesto a la pena capital si se le descubría alguna vez").

${ }^{52}$ Véase: Elio Lampridio, Historia Augusta, XVIII,43,6.

${ }^{53}$ Elio Lampridio, Historia Augusta, XVIII,21,3-5: "A los prefectos del Pretorio que él nombró, les confirió además la dignidad senatorial para que obtuvieran el rango y título de ilustrísimos, concesión que antes de su reinado fue excepcional o que estuvo totalmente en desuso, hasta tal punto que, si algún emperador quería nombrar un sucesor del prefecto del Pretorio, la enviaba la laticlavia por medio de un liberto, como dice Mario Máximo en la vida de muchos emperadores. Alejandro deseaba que los prefectos del Pretorio fueran senadores para que nadie que no fuera senador juzgara a los senadores romanos".

${ }^{54}$ Interesante resulta evocar el que Alejandro se avergonzara de ser llamado "Sirio". Los prejuicios en relación a los ciudadanos romanos de origen no itálico seguían existiendo aun cuando no gozaban de tanta fuerza como en tiempos de Septimio Severo. Elio Lampridio, Historia Augusta, XVIII,28,7: "volebat videri originem de Romanorum gente trahere, quia 
Sin embargo todas estas interesantes medidas sociales se frustraron por los problemas militares. La nueva Persia sasánida había reemplazado a los partos arsácidas y ello motivó una campaña agresiva en las fronteras orientales del Imperio. Alejandro respondió encabezando una expedición a Oriente, para lo cual tuvo que reclutar contingentes en el norte, en la frontera del Danubio. Con ello abría la posibilidad de que los germanos pudieran presionar por entrar en el Imperio. Ello ocurrió en efecto en 234. Alejandro debió retornar apresuradamente para hacer frente a los germanos sin poder conjurar del todo el peligro persa. Su deseo de terminar rápidamente por el conflicto fue interpretado por sus propios hombres como debilidad y ello provocó el motín en el que el emperador y su madre morirían asesinados en febrero de $235^{55}$.

f) Con el asesinato de Alejandro se ponía fin al último intento por rescatar al Imperio de su inevitable decadencia. El balance del reinado severiano resulta de dulce y agraz. A los intentos de Severo, Alejandro e incluso de Caracalla, por ampliar la base social del imperio extendiendo la ciudadanía romana a todos sus habitantes, promoviendo a los caballeros, y en síntesis a los sectores medios de la sociedad imperial, para devolver a Roma a los más activos y talentosos de sus ciudadanos, se debe contraponer el ejercicio de un poder político que se apoyó casi exclusivamente en las jerarquías militares, que se transformaron en los principales árbitros del poder como en los tiempos de Calígula y Nerón. El último proyecto de una administración civil para el imperio imaginado por Papiniano y Ulpiano terminó en realidad arrojando a dicha administración en manos de la casta militar, de la cual Maximino, el sucesor de Alejandro, sería el mejor exponente.

Finalmente, no podríamos olvidar que es con los Severos, que la idea de una verdadera monarquía, alejada ya de las ritualidades e ideales políticos del Principado, se afianza en las mentes de los romanos. Ha llegado la época en que los emperadores empezarán a considerarse depositarios de un poder divino, superior al del resto de las magistraturas políticas ${ }^{56}$.

eum pudebat Syrum dici, maxime quod quodam tempore festo, ut solent, Antiochenses, Aegyptii, Alexandrini lacessiverant conviciolis, et Syrum archisynagogum eum vocantes et archiereum" ("Deseaba que se creyera que era descendiente de una familia de romanos, por lo cual le avergonzaba que le llamaran Sirio, sobre todo por que en el transcurso de una festividad unos individuos de Antioquia, Egipto y Alejandría, como suele ser habitual entre ellos, le habían hostigado con pequeñas invectivas llamándole archisinagogo Sirio y sumo sacerdote”). En el mismo sentido, Historia Augusta, XVIII,40,7-9: "[...] in urbe tamen semper togatus fuit et in Italiae urbibus. praetextam et pictam togam numquam nisi consul accepit, et eam quidem quam de Iovis templo sumptam alii quoque accipiebant aut praetores aut consules. accepit praetextam etiam cum sacra faceret, sed loco pontificis maximi non imperatoris" ("[...] vestía siempre toga en la ciudad de Roma y en las ciudades de italia. Sólo utilizó la toga pretexta y la toga bordada durante el tiempo que ejerció el consulado, y precisamente aquélla que vestían también otros magistrados, como los cónsules o los pretores después de haberla tomado del templo de Júpiter. Utilizó también la pretexta cuando hacía sacrificios, pero si actuaba como Pontífice Máximo, no como emperador").

${ }^{55}$ Herodiano, Historia del Imperio Romano después de Marco Aurelio, VI,9,4-8, insiste en atribuir la responsabilidad de la muerte del emperador a su propia madre Julia Mamea, cuya codicia y cicatería serían el desencadenante de los asesinatos.

${ }^{56}$ Es la tesis que Ecfanto plantea en su Peri Basileias, la de unos gobernantes que son 


\section{LOS SEVEROS Y LA “CONSTITUTIO ANTONINIANA”}

Para analizar la Constitutio Antoniniana tanto en su emisión como en sus consecuencias, es necesario realizar algunas observaciones preliminares:

a) Como ya hemos indicado precedentemente, tras los tumultuosos hechos producidos como consecuencia del fin de Cómodo en el trono, la llegada al poder de Septimio Severo y sus sucesores, supuso un intento por reestablecer no solo el orden en la cúspide política del imperio sino, también, la paz romana en su sentido más precisamente cultural: un mundo, el orbis terrarum en el cual Roma garantiza la paz, la vida y la prosperidad de sus ciudadanos. Veremos si, desde el punto de vista cultural, este programa pudo ser cumplido.

b) $\mathrm{Al}$ respecto no hemos de olvidar el origen de los nuevos gobernantes. Septimio y su familia son africanos romanizados con una generosa mezcla de sangre siria, como tenía claro Dión Casio al describir a Caracalla. El dato resulta de capital importancia para comprender cuan profundamente se había desarrollado el proceso de romanización cultural en los confines del imperio y la forma desigual en que había calado en sus representantes ${ }^{57}$. Es decir, he aquí el resultado de una política cultural continuada a los largo de cuatro siglos por el cual el poder político se ha desplazado desde los itálicos hasta los provinciales, que se consideran a sí mismos tanto o más romanos que los nacidos en la urbe ${ }^{58}$.

c) Ya hemos apuntado que la historiografía jurídica ha descuidado el estudio sistemático del texto que comentamos. Se trata de una omisión lamentable que resulta tanto más grave cuanto que la significación de la Constitutio Antoniniana ha sido estudiada en profundidad a lo largo de años por parte de la historiografía

imagen de Dios instituidos para gobernar a los hombres en su nombre. Sobre este tratado consúltese: Burkert, W., "Peri Basileias", en Pseudoepigrapha, I: Entretiens sur l'Antiquité classique (1972), XXVIII, pp. 25-55; y SQUILLONI, Antonella, Il concetto di regno nel pensiero dello Pseudo Ecfanto: Le fonti e i trattati peri basileias (s.l., 1988). Sobre la idea de una monarquía Severiana disponemos del interesante estudio de MAZZA, M., Istituzioni giuridiche e realtà politiche nel Tardo Impero (III-V sec. D.C.) (Milán, 1976), pp. 1-62.

${ }^{57}$ Es paradojal recordar que aunque el primero de los Severos fue recibido como el salvador del Imperio, su propia hermana, que no era capaz de articular una sola frase en lengua latina, fue invitada cortésmente a retornar a su hogar, algo parecido a la hostil reacción de la aristocracia romana frente a la primera mujer del emperador. Véase: RostovTZEFF, Mijail, Historia social y económica del Imperio Romano (Madrid, 1998), I, p. 349.

${ }^{58}$ Mommsen, Theodor, cit. (n. 28), p. 465: “[...] la Cartago romana no iba muy a la zaga de Alejandría en cuanto a censo de población y a riqueza y era, indiscutiblemente, la segunda ciudad de la parte latina del imperio después de Roma, la más animada y tal vez también la más corrompida de todo el Occidente, a la par que el centro más importante de la cultura y la literatura latinas [...]. Los africanos no carecían tampoco de aplicación ni de talento; por el contrario, en el África se daba tal vez más importancia que en ninguna otra parte del imperio a la enseñanza latina y al lado de ella a la griega y a la meta de ambas, o sea a la cultura general del espíritu, y las escuelas se hallaban muy desarrolladas. El filósofo Apuleyo, bajo Antonino Pío, y el famoso escritor cristiano San Agustín, descendientes ambos de familias acomodadas -el primero nació en Madaura y el segundo en Negaste (sic), pueblecillo cercano a aquella ciudad-, cursaron los primeros estudios en la escuela de su pueblo natal". 
clásica $^{59}$. Son destacables los trabajos de don Álvaro d'Ors ${ }^{60}$, Wolff ${ }^{61}$ y Benario ${ }^{62}$. En el ámbito académico anglosajón, siempre fecundo en estudios clásicos podemos citar los trabajos de Lawton Sherman ${ }^{63}$ y Jones ${ }^{64}$. Y en el ámbito nacional, los documentados trabajos del doctor Bancalari.

d) Son muy numerosos los problemas que ha supuesto a los expertos el estudio de la Constitutio Antoniniana de Civitate, desde la publicación del denominado Papiro de Giessen ${ }^{65}$ No 40, en $1910^{66}$.

\section{Antecedentes.}

Hasta antes de la publicación del Papiro de Giessen nuestras noticias de la Constitutio eran fragmentarias y parciales. Pero con la edición de la obra de Meyer surge toda una nueva investigación que hasta hoy no concluye.

El papiro procede de Egipto, de la localidad de Heptakomia en la región de Tebaida.

Contiene en estricto rigor, textos fragmentarios de tres constituciones imperiales. Dos de ellas están fechadas, la primera el 11 de julio de 212 y la otra tras la insurrección alejandrina de 215. Sin embargo es el tercer fragmento el que contiene el texto que reproduciremos enseguida. El emperador Caracalla afirma querer dar gracias a los dioses por haberle concedido una victoria y para ello concede a los peregrinii la ciudadanía romana, de manera de integrarlos a todos en el culto imperial $^{67}$. Finalmente existen alusiones a la majestad del pueblo romano, típica construcción de orden retórico político.

Resulta interesante constatar que no todo el mundo académico acepta que el texto del Papiro de Giessen sea realmente la Constitutio Antoniniana ${ }^{68}$. Lamentablemente más de un tercio del papiro se ha perdido por el deterioro natural y la dificultad de su conservación por lo que resulta poco menos que imposible afirmar o descartar del todo esta posibilidad ${ }^{69}$.

\footnotetext{
${ }^{59}$ En los últimos años, el vacío a que nos referimos ha sido salvado con la labor de expertos italianos y chilenos, entre los que destaca la figura del doctor Alejandro Bancalari.

${ }^{60}$ Véase: D'Ors, Álvaro, cit. (n. 17).

${ }^{61}$ Véase: WolfF, Hartmut, cit. (n. 17).

${ }^{62}$ Véase: Benario, Herbert W., cit. (n. 17), pp. 188-196.

${ }^{63}$ Véase: Lawton Sherman, Charles, cit. (n. 17), pp. 33-47.

${ }^{64}$ Véase: JONES, A.H.M., cit. (n. 17), pp. 223-235.

${ }^{65} \mathrm{El}$ texto se encuentra depositado en el Museo de la Sociedad Histórica de Hesse Superior, en la ciudad de Giessen. Escudero, José Antonio, cit. (n. 20), p. 116.

${ }^{66}$ Erróneamente Le Gall y Le Glay fechan la publicación en 1900. Cfr. Le GALL, Joel - LE GLaY, Marcel, El Imperio Romano (Madrid, 1995), p 491. Ella se realizó el año 1910 por MeYER, P. M., Griechische Papyri im Museum des Giessen 2 (Lepzig-Berlín, 1910). Véase, en el mismo sentido: Bancalari, Alejandro, La "Constitutio Antoniniana", cit. (n. 17), p. 58.

${ }^{67}$ Véase: Le Gall, Joel - LE GLAY, Marcel, cit. (n. 66), p. 491.

${ }^{68}$ Véase: Le Gall, Joel - Le Glay, Marcel, cit. (n. 66), p. 491; Jones, A. H. M., cit. (n. 17); y Bickermann, E., Das Edickt des Kaisers Caracalla in P. Giessen 40 (Berlín, 1926), p. 488, que sostiene que los fragmentos del papiro serían incompatibles con el texto auténtico de la Constitutio, por lo que atribuye el contenido del Papiro Giessen a un edicto posterior que habría extendido la ciudadanía romana a los bárbaros establecidos en el Imperio.

${ }^{69}$ Véase: Benario, Herbert W., cit. (n. 17), p. 191.
} 


\section{El texto.}

La versión latina fragmentaria reconstituida es la siguiente: "Imperator Caesar Marcus Aurelius Seuerus Antoninus Augustus dicit: Nunc uero .... potius oportet querellis et libellis sublatis quaerere quomodo diis immortalibus gratias agam, quod ista uictoria.... me seruauerunt. Itaque existimo sic magnifice et religiose maiestati eorum satisfacere me posse, si peregrinos, quotiens cumque in meorum hominum numerum ingressi sint, in religiones (?) deorum inducam. Do igitur omnibus peregrinis, qui in orbe terrarum sunt, ciuitatem Romanorum, manente omni genere ciuitatum, exceptis dediticiis. Oportet enim multitudinem non solum omnia . . . . sed etiam uictoria circumcingi. Praeterea hoc edictum augebit (?) maiestatem populi Romanorum cum facta sit eadem aliorum (?) (peregrinorum?) dignitas [...]"70.

\section{Significado.}

Es conveniente reseñar brevemente las diversas cuestiones que surgen a propósito del significado real de la Constitutio Antoniniana.

a) El Papiro Giessen no contiene fecha, por lo que aún hoy existe discusión sobre el momento preciso en que se produjo la dictación de la Constitutio. Las posibles fechas son los años 212 o 215 , pero la tendencia de la historiografía se inclina por la primera debido a que ello explicaría la "victoria" a la que alude Caracalla, sería la fecha en que la muerte de Geta, supuesto conspirador en contra de Caracalla y víctima de su propia mano, le había elevado al poder absoluto ${ }^{71}$. Como veremos, las fuentes contemporáneas a Caracalla o no la mencionan o lo hacen solo a la pasada, por lo que resulta explicable también, la omisión de su fecha ${ }^{72}$.

b) En segundo lugar la importancia que se atribuyó a la Constitutio en su propia época $^{73}$. Es interesante constatar que ni la Historia Augusta, ni Herodiano

${ }^{70}$ Fuente castellana: Edicto de Caracalla, Papiro Giessen 40, col. 1, traducción de Jaime Alvar, en García Moreno, Luis y otros, Historia del mundo clásico a través de sus textos, II: Roma (Madrid, 1999), p. 242. "El emperador César Marco Aurelio Severo Antonino Augusto declara: [...] puedo manifestar mi agradecimiento a los dioses inmortales que me protegen [...] considero, pues, que puedo [...] servir a su grandeza [...] haciendo participar conmigo en el culto de los dioses a todos los que pertenecen a mi pueblo. Por ello concedo a todos los peregrinos (?) que están sobre la tierra la ciudadanía romana [salvaguardando los derechos de las ciudades] con la excepción de los dediticios. Pues es legítimo que el mayor número no sólo esté sometido a todas las cargas, sino que también esté asociado a mi victoria. Este edicto será [...] la dignidad del pueblo romano". La versión latina del original griego, ha sido adaptada por Eduardo Andrades Rivas. El estudio más característico sobre el griego original y su posible reconstrucción se encuentra en Heichelheim, F. M., The text of the "Constitutio Antoniniana" and the Three Other Decrees of the Emperor Caracalla Containes in Papyrus Gissensis40, en The Journal of Egyptian Archaeology 26 (1941), pp. 10-22, versión electrónica íntegra disponible en: http://www.jstor.org/pss/3854517 (18-04-2009).

${ }^{71}$ Véase: Le Gall, Joel - Le Glay, Marcel, cit. (n. 66), p 492. Al respecto, consultar el estado de la cuestión en Bancalari, Alejandro, La "Constitutio Antoniniana", cit. (n. 17), pp. 59-61.

${ }^{72}$ Un resumen de las tesis sobre la datación de la Constitutio puede encontrarse en MiLlaR, Fergus, The Date of the "Constitutio Antoniniana", en The Journal of Egyptian Archaeology 48 (1962), pp. 124-131, versión electrónica disponible en http://www.jstor.org/stable/3855791 ((5-01-2009).

${ }^{73}$ BANCALARI, Alejandro, La" civitas" romana, cit. (n. 17), p. 86, afirma que: "La indiferencia 
la mencionan siquiera indirectamente. Dión Casio habla de ella en dos oportunidades, en el discurso de Mecenas a Augusto y en la descripción de los motivos financieros que habrían llevado a Caracalla a dictarla ${ }^{74}$. Igualmente la menciona Ulpiano al comentar el Edicto Perpetuo ${ }^{75}$, San Agustín en La Ciudad de Dios ${ }^{76}$ y Justiniano en el Corpus iuris civilis, específicamente en el texto de las Novellae, aunque erróneamente se atribuye su autoría a Antonino Pío ${ }^{77}$. Existen también algunas fuentes secundarias que la mencionan, como Sexto Aurelio Víctor ${ }^{78}$ y San Juan Crisóstomo ${ }^{79}$.

c) La historiografía está también dividida en su valoración de la Constitutio. Algunos estiman que ella fue "una de las decisiones de mayor repercusión social del siglo III" 80 . Y una de las mayores contribuciones de Roma a la civilización ${ }^{81}$. Otros, siguiendo a Dión Casio ${ }^{82}$, según se ha dicho, destacan los propósitos meramente tributarios que habría perseguido Caracalla en su dictación ${ }^{83}$.

de los historiadores, juristas y literatos por registrar el edicto es inaudito e increíble".

${ }^{74}$ Es precisamente con Dión Casio que se inicia la tradición de explicar la Constitutio como una simple medida para aumentar la fiscalidad impositiva, ya que al gravar a los antiguos peregrinii como nuevos ciudadanos e imponerles el tributo a las herencias, Caracalla habría logrado recaudar nuevos fondos para financiar sus megalómanas ambiciones. Véase: LE GALL, Joel - LE GLAY, Marcel, cit. (n. 66), p. 491.

${ }^{75}$ Véase: Le Gall, Joel - Le GlaY, Marcel, cit. (n. 66), p. 491.

${ }^{76}$ San Agustín, La Ciudad de Dios, V,17: "ut omnes ad Romanum imperium pertinentes societatem acciperent civitatis et Romani cives" ("ordenando que todos los vasallos que pertenecían al Imperio romano gozasen de la naturaleza y privilegio de la ciudad, disfrutando el honor de los ciudadanos romanos").

${ }^{77}$ Véase: BANCALARI, Alejandro, La "Constitutio Antoniniana.", cit. (n. 17), p. 63.

${ }^{78}$ Sexto Aurelio Víctor (320-390). Originario de África, de la misma patria de Septimio Severo, Leptis Magna, admirador de los grandes gobernantes del siglo II, desempeñó variadas funciones públicas como gobernador provincial y prefecto de la ciudad de Roma tras la muerte del Emperador Juliano, su protector. Ocupa dicho cargo hasta por lo menos el 389. Escritor de carácter moralizante más que histórico, su obra más conocida es el Liber de Caesaribus, compuesto de 42 capítulos que se dedican a uno o más emperadores. Existe discusión acerca de la autoría total del liber, pero hoy pensamos que su autor quiso presentar la historia de Roma a través del relato sintético de sus mejores gobernantes. Aurelio realiza una defensa de la política romanizadora de la República y el Imperio. En este contexto menciona a la Constitutio Antoniniana. Véase: FerNÁNDEZ, Gonzalo, Un historiador pagano del siglo IV D.C. Sexto Aurelio Victor, en Arbil 120, publicación electrónica: http://www.arbil.org/120sext. htm (20-04-2009).

${ }^{79}$ Véase: BanCalari, Alejandro, La "Constitutio Antoniniana.", cit. (n. 17), p. 63.

${ }^{80}$ Es la opinión de Mangas, Julio, Historia universal. Edad Antigua: Roma (Barcelona, 1999), p. 387-388, aun cuando este autor reconoce que la Constitutio vino a "consagrar jurídicamente una situación de hecho por la que los nuevos ciudadanos mejoraban su estatuto jurídico sin necesidad de percibir mejoras en sus condiciones de vida. Con tal decisión, se conseguía una enorme simplificación de la administración a efectos de elaboración de los censos.

${ }^{81}$ Véase: Lawton Sherman, Charles, cit. (n. 17), p. 47.

${ }^{82}$ Debe recordarse la hostilidad que Dión Casio manifiesta hacia Caracalla, por lo que resulta lógico que haya querido restarle importancia a su obra, atribuyéndole propósitos simplemente fiscales. Véase: BENARIO, Herbert W., cit. (n. 17), p. 188.

${ }^{83}$ Rostovzeff, Bickermann, citados en la obra de Benario y el mismo Lawton Sherman al inicio de su ensayo, restan importancia a la dictación del edicto y lo reducen a una medida de fiscalidad. Véase: Lawton Sherman, Charles, cit. (n. 17), p. 34. En el mismo sentido se 
d) Debe determinarse la razón por la que, con posterioridad a la obra de Caracalla, siguieron en vigencia instituciones como el Pretor Peregrino en la Urbe, lo que demostraría que luego del 212 siguieron existiendo peregrinii, contrariamente a lo que pudiera concluirse de la sola lectura del texto de la Constitutio ${ }^{84}$. Hoy, la moderna interpretación coincide en explicar esta circunstancia, al decir de Le Gall y Le Glay, cuando se afirma que "todos los habitantes libres del mundo romano convertidos en ciudadanos podían, con su ciudadanía romana, conservar su derecho propio y su estilo de vida y solo los denominados dediticios no gozaban de tales privilegios" $" 85$. El estudio del doctor Bancalari nos proporciona noticia de importantes monografías dedicadas al estudio del documento ${ }^{86}$.

e) Como quiera que sea, gracias a la Constitutio, jurídicamente las ciudades no romanas dejan de considerarse como personas privadas ${ }^{87}$ dotadas de un estatuto propio y excluyente y pasan a ser parte plena del orbis romanus.

\section{Beneficiarios.}

Como bien lo expresa el Papiro de Giessen y las fuentes que aluden a la Constitutio, ella beneficia a todos los hombres libres del imperio. Debemos incluir dentro de esta categoría en forma amplia, a los miembros de las familias, mujeres e hijos, de los nuevos ciudadanos y sus descendientes.

Sin embargo, pese a esta amplitud temporal de la concesión, que debería interpretarse en el sentido de que a partir de ese momento todos los hijos de ciudadanos romanos debían seguir la misma condición, existe evidencia documental en papiros e inscripciones acerca de individuos que aún luego de la dictación de la Constitutio no eran ciudadanos: la prueba histórica es débil pero no debe ser despreciada: campesinos egipcios que no usan de nombres romanos ${ }^{88}$, en el Rhin y el Danubio se continúa distinguiendo entre ciudadanos romanos y los que no lo $\operatorname{son}^{89}$ y diplomata que se conceden a soldados licenciados, que se casan con mujeres que no son ciudadanas ${ }^{90}$. En definitiva se puede pensar que aunque la Constitutio tuvo un efecto general a lo largo y ancho del imperio, pudieren haber habido grupos minoritarios que no fueren beneficiados inmediatamente por ella ${ }^{91}$.

pronuncia Piganiol, André, cit. (n. 29), p. 375 s.: "El derecho de ciudadanía romana pierde toda su valía, puesto que se concede a todos los habitantes del Imperio. Así desaparece la distinción, nacida de la conquista, entre romanos y súbditos. El imperio romano pierde el carácter de imperio colonial que había conservado hasta entonces".

${ }^{84}$ Véase: Le Gall, Joel - Le GLAY, Marcel, cit. (n. 66), p 491.

${ }^{85}$ Véase: Le Gall, Joel - Le Glay, Marcel, cit. (n. 66), p 492.

${ }^{86}$ Véase: Bancalari, Alejandro, La Constitutio Antoniniana, cit. (n. 17), pp. 57-58.

${ }^{87}$ Véase: IgLesias-Redondo, Juan, Repertorio Bilingüe de definiciones, reglas y máximas jurídicas romanas (Madrid, 1986), pp. 134-135.

${ }^{88}$ Aunque perfectamente pudieron tenerlos y no utilizarlos solo por razones de tradición o uso.

${ }^{89}$ En este caso podría tratarse de bárbaros recién llegados a las fronteras o limes del Imperio.

${ }^{90}$ Aunque también pudiere tratarse de libertas dediticia.

${ }^{91} \mathrm{Al}$ respecto consultar: Millar, Fergus (editor), Historia Universal siglo XXI, VIII: El Imperio Romano y sus pueblos limítrofes. El mundo mediterráneo en la Edad Antigua (México, 1975), IV, pp. 84-85. 


\section{Los "dediticii".}

Finalmente debemos ocuparnos de una de las cuestiones que han sido más debatidas en el estudio de la Constitutio. La identidad de los aludidos "dediticios" en la Constitutio.

Fergus Millar enumera algunas posibilidades sobre el particular: Podría tratarse de pueblos recientemente conquistados ${ }^{92}$, personas que no vivieran en ninguna ciudad conocida (los llamados peregrini nullius civitatis) ${ }^{93}$ o esclavos libertos sujetos a esta condición ${ }^{94}$.

En el plano jurídico, Gayo aclara los alcances de esta expresión: "Vocantur autem peregrini dediticii hi, qui quondam adversus populum Romanum armis susceptis pugnaverunt, deinde victi se dediderunt" ${ }^{\prime 9}$.

Asimismo hay en Gayo una declaración que apoyaría el sentido indicado, de que los dediticios son los peregrinos rendidos a Roma: "Pessima itaque libertas eorum est, qui dediticiorum numero sunt; nec ulla lege aut senatus consulto aut Constitutione principali aditus illis ad civitatem Romanam datur. Quin etiam in urbe Roma vel intra centesimum urbis Romae miliarium morari prohibentur; et si qui contra ea fecerint, ipsi bonaque eorum publice venire iubentur ea condicione, ut ne in urbe Roma vel intra centesimum urbis Romae miliarium serviant neve umquam manumittantur; et si manumissi fuerint, servi populi Romani esse iubentur. Et haec ita lege Aelia Sentia conprehensa sunt ${ }^{\prime 26}$. Benario ha expresado que el sentido de la expresión dediticio pudiere referirse también a los manumitidos según la ley Elia Sentia citada, para lo cual razonando jurídicamente, nos recuerda que la Constitutio, revistiendo la forma jurídica de un oratio princeps no podría derogar una ley formal como la Elia Sentia ${ }^{97}$.

${ }^{92}$ Tesis que compartimos. Véase: BANCALARI, Alejandro, Coexistencia, cit. (n. 17), p. 28. La opinión del doctor Bancalari ilustra el estado de la cuestión en nuestros días y parece ser que no habrá novedades en el futuro cercano, mientras nuestro conocimiento de las fuentes permanezca igual.

${ }^{93}$ Es la tesis que impuso Mommsen y que subsistió hasta la publicación del Papiro Giessen. También la defenderá Schönbauer. El profesor Jones indica sobre este punto, que los egipcios no alejandrinos que no habitaban ciudades podrían ser considerados dediticios. Cfr. JonEs, A. H. M., cit. (n. 17), p. 226 y 232.

${ }^{94}$ Véase: Millar, Fergus (editor), Historia universal, cit. (n. 91), p. 84.

${ }^{95} \mathrm{GAYO}$, Institutiones 1,14: "Se llaman peregrinos dediticios quienes en tiempos anteriores lucharon contra el pueblo romano a mano armada y luego, vencidos, se entregaron incondicionalmente".

${ }^{96} \mathrm{GaYO}$, Institutiones 1,26-27. "Así pues, vemos que la libertad de los que pertenecen a esta clase de dediticios es la de peor condición, y por ninguna ley ni senadoconsulto, ni constitución imperial se les concede participar de la ciudadanía romana. Es más, incluso se les prohíbe permanecer en Roma o a menos de cien millas de ella. Si alguno de ellos infringiera esa prohibición, se ordena que sea vendido públicamente él y todos sus bienes, quedando en condición tal que ni en la propia ciudad de Roma ni a cien millas de ella puede servir como esclavo ni ser manumitido jamás; y si llegara a ser manumitido, se haría esclavo del pueblo romano. Así está dispuesto en la ley Elia Sencia".

${ }^{97}$ Discrepamos del punto. En el año 212 la distinción entre un oratio princeps y una ley había perdido toda importancia, por lo que no hay problemas en concluir que la Constitutio podría afectar a los esclavos manumitidos. Cfr. Benario, Herbert, cit. (n. 17), pp. 193-196. 
Recordemos también que la Constitutio Antoniniana excluyó del beneficio a los Latini Iuniani ${ }^{98}$.

Como venimos diciendo, la cuestión hoy en día ha alcanzado cierto acuerdo en el sentido de identificar a los dediticios con pueblos recientemente asimilados ${ }^{99}$, pero queda planteado el problema de resolver cuáles podrían ser esos pueblos ${ }^{100}$. Las grandes conquistas romanas habían cesado para el Imperio en tiempos de los Antoninos.

Más allá de estas discusiones, es claro que hacia fines del imperio romano la ciudadanía era universal y hacía mucho tiempo que se había perdido la noción de dediticios ${ }^{101}$.

\section{Importancia de la "Constitutio" en su época.}

No tenemos razones de peso para dudar de la veracidad de los invocados motivos religiosos que inspiraron a Caracalla a dictar la Constitutio; la personalidad profundamente egocéntrica del emperador bien pudiere significar que se convenció a sí mismo de que los dioses le protegían ${ }^{102}$. De la misma manera es posible aceptar que hubo también motivaciones económicas como señala desde un comienzo Dión Casio ${ }^{103}$. Asimismo debemos recordar un antecedente frecuentemente olvidado respecto de la ampliación de la ciudadanía y es que el proceso se había intensificado notoriamente bajo el reinado del padre de Caracalla, Septimio Severo quien simplificó muchos requisitos y formalismos para facilitar el acceso a la ciudadanía. Por lo que su hijo, al proceder en la forma indicada se habría inspirado directamente en la política gubernativa de su padre. ${ }^{104}$ Con todo no

${ }^{98}$ Se trata de esclavos libertos manumitidos no solemnemente.

${ }^{99}$ Un bosquejo sintético del estado de la cuestión se contiene en Alvarado Planas, Javier - Montes Salguero, Jorge - Pérez Marcos, Regina - Sánchez González, María Dolores, cit. (n. 20), p. 85. Con todo, el único estudio procedente de la historiografía histórico-jurídica que realiza una exposición sintética y a la vez crítica sobre las distintas teorías acerca de los dediticios es la obra del profesor doctor José Antonio Escudero. El jurista expone y analiza las tesis clásicas de Meyer y Segré y la tesis doctoral del profesor d'Ors, quien postulaba que la Constitutio sólo excluía a los dediticios de la ley Elia Sencia. Asimismo, Escudero, José Antonio, cit. (n. 20), pp. 115-118, sostiene que luego del año 212 la distinción jurídica entre ciudadanos del imperio carece de sentido, cobrando importancia la diferenciación que se realiza entre los órdenes sociales de honestiores y humiliores. Véase:.

${ }^{100}$ En su trabajo The "Dediticii" of the "Constitutio Antoniniana", publicado en 1954 el profesor Herbert Benario analiza esta conclusión, con la que concuerda parcialmente, siguiendo a Berger. Véase: Benario, Herbert, cit. (n. 17), pp. 192-194. Asimismo Jones participa de esta opinión, al señalar que los romanos, desde sus conquistas durante la República, raramente sometían a los conquistados por largo tiempo a la condición de dediticios. Jones, A. H. M., cit. (n. 17), p. 229.

${ }^{101}$ Véase: Jones, A. H. M., cit. (n. 17), p. 227.

${ }^{102}$ Véase: Le Gall, Joel - Le Glay, Marcel, cit. (n. 66), p. 492.

${ }^{103}$ Sobre las implicancias económicas que la Constitutio representó en Egipto, véase: Bell, H. I., The "Constitutio Antoniniana" and the Egyptian Poll-tax, en The Journal of Roman Studies 37 (1947) 1 y 2, pp. 17-23. Hay versión electrónica disponible en http://www.jstor. org/stable/298450 (13-02-2009).

${ }^{104}$ Lawton Sherman, Charles, cit. (n. 17), pp. 46-47, lo señala expresamente: "The granting of universal citizenship was the logical outcome of these measures". 
debemos pensar que la dictación de la Constitutio significó que todos los grupos sociales fueran admitidos en igualdad de condiciones a gozar de los beneficios de la ciudadanía ${ }^{105}$. Es conocida al respecto la mantención de la persecución a los cristianos bajo el gobierno de Caracalla ${ }^{106}$.

\section{Importancia de la "Constitutio" en la historia.}

El doctor Bancalari sintetiza de esta manera la contribución de la Constitutio en la historia: "El edicto de Caracalla debemos concebirlo y estudiarlo, en consecuencia, como un proceso lineal, irreversible, lógico, natural y en calidad de un punto de llegada de una integración o aculturación que se iba configurando con antelación entre provinciales y romanos para la conformación de un solo cuerpo político y jurídico"107.

Coincidimos con esta forma de concebir la importancia del acto de Caracalla y agregaríamos que este proceso manifiesta una evidente e indudable faceta cultural, la Constitutio no es más que un hito en el proceso irreversible de transformar en romanos a quienes originalmente fueron sus pueblos aliados o incluso vencidos ${ }^{108}$. Es ésta una cuestión única en la historia de nuestra civilización y a nuestro juicio la mayor gloria de Roma que alcanza aún para honrar la memoria de un gobernante tan indigno como Caracalla. Con la Constitutio, la Pax Romana impone el derecho romano como sistema jurídico común a todo el orbis terrarum. "Pacis imponere morem" ${ }^{\prime 109}$.

\section{Importancia de la "Constitutio" en el Derecho.}

La importancia de la obra de Caracalla para el derecho puede expresarse desde dos puntos de vista contrapuestos ${ }^{110}$ :

a) El derecho romano territorial: En primer lugar la de aquellos que sostienen que con la dictación de la Constitutio se habría impuesto la vigencia de las insti-

\footnotetext{
${ }^{105}$ Un interesante estudio sobre las categorías de soldados de las legiones, beneficiados por la Constitutio se encuentra en Gilliam, J. F., Dura Rosters and the Constitutio Antoniniana, en Historia 14 (1965), pp. 74-92.

${ }^{106}$ Véase: KereszTes, Paul, The "Constitutio Antoniniana" and the Persecutions Under Caracalla, en The American Journal of Philology 91 (1970) 4, pp. 446.459. Hay versión electrónica disponible en http://www.jstor.org/stable/293084 (02-03-2009).

${ }^{107}$ Véase: BanCALARI, Alejandro, La "Constitutio Antoniniana", cit. (n. 17), p. 67.

${ }^{108}$ Véase: BANCALARI, Alejandro, Relación, cit. (n. 17), p. 27, lo expresará en su estudio sobre la Constitutio Antoniniana y la Imitatio Alexandri de Caracalla: "La Constitutio Antoniniana como parte de un proceso histórico de maduración, afirmó la idea de un imperio universal, ecuménico y es explicada por un coherente y amplio diseño político, religioso y jurídico [...] Con el edicto de Caracalla, se produce un hecho sorprendente e inédito al terminar explícitamente la división entre romanos y súbditos; se unen vencedores y vencidos; desaparecen los diferentes posibles nacionalismos y regionalismos de cada provincia y localidad, surgiendo a juicio de E. Barker una "nacionalidad mediterránea", o sea, una unidad política, jurídica, geográfica, una communitas, constituida por un imperio mediterráneo”.

${ }^{109}$ Véase: LaWton Sherman, Charles, cit. (n. 17), p. 47.

${ }^{110}$ Uno de los primeros estudios de que disponemos y que aborda esta ardua cuestión es el de SCHÖNBAUER, Ernst, Reichsrecht gegen Volksrecht? Studien über die Bedeutung der "Constitutio Antoniniana" für die röm. Rechtsentwicklung (1931), pp. 277 ss.
} 
tuciones romanas en forma universal con lo cual la vigencia de los derechos y/o costumbres indígenas habría cesado como consecuencia directa del acto legislativo del Príncipe ${ }^{111}$. Ello resulta discutible a la luz de lo que diremos enseguida, pero lo que es innegable es que a partir del año 212 puede hablarse de un derecho romano territorial, es decir, un derecho aplicado en un ámbito geográfico determinado, sin considerar la condición u origen personal de aquellos a quienes se aplique. Esta es una de las mayores glorias del derecho romano y se encuentra entre los máximos logros que ha legado a los sistemas jurídicos contemporáneos. La superación del principio primitivo de la personalidad del derecho por el de la territorialidad es una contribución romana siempre destacada por los historiadores del Derecho ${ }^{112}$. No obstante lo anterior, no puede negarse que la Constitutio devendrá en un factor de vulgarización jurídica. Se trata aquí de ponderar en qué medida fue posible que gracias a la Constitutio se impusiera lentamente una nueva concepción del derecho. Y hemos de considerar la fragilidad intelectual de esta construcción. A la caída de Roma, este principio se perderá con una facilidad inaudita en todo Occidente para aquellos que, durante más de dos siglos, habían estado sujetos a él. Los reinos bárbaros, salvo el visigodo, no están en condiciones de comprender culturalmente lo que la territorialidad significa. Habrá que esperar a la formación de los estados modernos y a la influencia en la cultura jurídica occidental del ius commune para que el principio de territorialidad sea restaurado.

Asimismo, debemos tener presente que la difusión de la ciudadanía en los siglos anteriores a la Constitutio había preparado culturalmente a la población para usar de las instituciones del derecho romano. Por lo que, en la medida en que la ciudadanía estuviera más difundida, el proceso de unificación jurídica resultaría más viable ${ }^{113}$.

b) Supervivencia de los derechos locales: La tesis contraria indica que dado el diverso grado de romanización que experimentaban las provincias dependientes de Roma hacia inicios del siglo III resulta lógico concluir que la aplicación de las instituciones del derecho romano, no podía lograrse del mismo modo en todos los territorios que integraban el Imperio. Algunas provincias como las de Hispania ${ }^{114}$

${ }^{111}$ Véase: Alvarado Planas, Javier - Montes Salguero, Jorge - Pérez Marcos, Regina - Sánchez GonzÁlez, María Dolores, cit. (n. 20), p. 85: “Con la concesión general se logró la territorialización del Derecho [...] es decir un derecho único para todos los habitantes del territorio".

${ }^{112}$ Véase: Escudero, José Antonio, cit. (n. 20), 115-118.

${ }^{113}$ Con relación a las provincias Occidentales, Spagnuolo Vigorita, Tullio, Diritti locali e modello romano nel principato, en GONZÁLEZ F., Julián (editor), Roma y las provincias, realidad administrativa e ideología imperial (Madrid, 1994), p. 221, lo afirma expresamente: "Nelle zone in cui le forme cittadine romane ebbero maggior diffusione (le provinci occidentali, dunque sia pur con rilevanti differenze locali e cronologiche), il processo di unificazione giuridica fu certo più sensibile".

${ }^{114}$ En relación con este punto, Pérez-Prendes Muñoz de Arraco, José Manuel, cit. (n. 20), p. 281, defiende la tesis de que incluso en Hispania el derecho romano no podía aplicarse totalmente, "Podemos considerar que en nuestra Península, dado que no podía conocerse bien y, por tanto, no podía aplicarse radicalmente el Derecho romano, no pudo desaparecer el Derecho indígena, al menos de ciertas regiones. Por ello, más que difundirse el Derecho 
y la Galia Narbonense, podían acceder a la aplicación del derecho romano de una forma mucho más plena que las provincias de Britania o las del Oriente Próximo. Y precisamente allí donde la romanización es menos intensa, será más posible el que rija simultáneamente un orden jurídico "oficial”, romano conjuntamente con un derecho indígena consuetudinario "no oficial"115. Asimismo hay prueba suficientemente contundente para demostrar que, incluso en Hispania, había una larga tradición de pluralismo normativo, aún dentro del propio sistema romano, que superponía diversas fuentes como leyes municipales, leyes del lugar, leyes de ciudadanía y costumbre ${ }^{116}$. Por ello no es inconcebible que la población haya tendido a cierto grado de pluralidad normativa aún con posterioridad a la Constitutio Antoniniana ${ }^{117}$. Le Gall y Le Glay lo aceptan expresamente al indicar que "En todo caso, y fueran cuales fueren los móviles, la Constitutio Antoniniana remataba jurídicamente la unidad del mundo romano, sin por ello abolir las "patrias particulares" ${ }^{118}$. El ejemplo de la supervivencia del estatuto egipcio o código del Idiologos ${ }^{119}$ que reglamentaba las instituciones jurídicas aplicables a los egipcios no romanos es un ejemplo de esta supervivencia. Se trata de un interesante caso de aplicación persistente de instituciones propias del antiguo mundo indígena que incluso fueron oficialmente modificadas por la Constitutio Antoniniana.

\section{Mundo romano, mundo ciudadano, elusiva asimilación.}

En consideración a lo que indicamos, cabe preguntarse si con la Constitutio Antoniniana ¿se produce la asimilación entre lo romano y lo ciudadano? La respuesta admite una distinción básica: Desde el punto de vista de las fuentes documentales clásicas posteriores a la dictación de la Constitutio Antoniniana y desde el punto de vista de la historiografía moderna.

Para la comprobación del primer punto de vista podemos consultar la obra de Menandro el rétor, "Dos tratados de retórica epidíctica”, obra compuesta seguramente entre el 272 y el 295, es decir, más de sesenta años después de la dictación de la Constitutio Antoniniana: el retórico nos ofrece algunas referencias a la existencia de una sola ley que gobierna a todas las ciudades romanas ${ }^{120}$; de

romano, se aceleró su vulgarización, aun cuando desde el punto de vista teórico se alcanza el apogeo de la romanización jurídica.

${ }^{115}$ Es la conclusión de Levaggi, Abelardo, Manual de Historia del Derecho argentino (Castellano-Indiano/Nacional). Parte general(Buenos Aires, 1991), I, pp. 27-28: "Teóricamente desde este momento (Nota del autor: desde la dictación de la Constitución Antoniniana) sólo existió un Derecho en todo el Imperio: el Derecho Romano. Teóricamente, porque en realidad no era así”.

${ }^{116}$ Spagnuolo Vigorita, Tullio, cit. (n. 113), p. 216: "Il pluralismo normativo conobbe una vicenda non dissimile. Gli ordinamenti locali sono richiamati abbastanza spesso nella letteratura giuridica”.

${ }^{117}$ En este sentido se pronuncia SPagnUolo Vigorita, Tullio, cit. (n. 113), p. 224, en la conclusión de su estudio sobre el particular.

${ }^{118}$ Véase: Le Gall, Joel - Le Glay, Marcel, cit. (n. 66), p 492.

${ }^{119}$ Véase: LaWton Sherman, Charles, cit. (n. 17), p. 33-47, lo estudia in extenso, y señala las modificaciones y derogaciones parciales que importó para el régimen del Idiologos la emisión de la constitución de Caracalla.

${ }^{120}$ Véase: MEnandro, el rétor, Dos tratados de retórica epidíctica, Tratado I, III, 360, 11-16. 
que ellas se rigen por las leyes comunes de los romanos ${ }^{121}$, aunque admite que existen usos y costumbres diversas de una ciudad a la otra y acepta la posibilidad de que existan todavía ciudades libres en donde se aplican sus propias instituciones jurídicas ${ }^{122}$. Dicho lo cual podemos concluir, que, al menos para Menandro, la identificación se ha producido, aunque salvando su reconocimiento a las costumbres particulares de cada ciudad y a la existencia de ciudades todavía no romanas dentro del imperio.

En un sentido similar se pronuncia Modestino, el jurista tardo clásico. Refiriéndose a la unidad jurídica alcanzada gracias a la Constitutio Antoniniana pronunciará la famosa sentencia: "Roma communis nostra patria est" 123 . Otro interesante caso es el de Gregorio Taumaturgo, el intelectual originario del Ponto, que reconoce la importancia de la Constitutio, en la educación jurídica de su tiempo ${ }^{124}$.

En cuanto a los estudios historiográficos sobre el particular es preciso destacar el ya citado del profesor Tullio Spagnuolo en el que afirma que el pluralismo jurídico fue apenas debilitado por la dictación de la Constitutio Antoniniana de Civitate, por lo que continuó siendo una realidad ${ }^{125}$. A conclusión parecida llega el profesor Bancalari en su estudio sobre la coexistencia jurídica entre el derecho romano y los derechos locales ${ }^{126}$.

Desde el punto de vista jurídico positivo se puede llegar a una conclusión similar. El derecho común se vuelve sinónimo de derecho general para el Imperio, aun cuando es posible aceptar la vigencia actual y precisa de derechos especiales o ius proprium de cada localidad provincial ${ }^{127}$.

\section{La prueba de la Epigrafía.}

Varias muestras de la inscripción epigráfica avalan lo que venimos afirmando. Así podemos señalar las inscripciones de Afrodisia en la actual Turquía, que datan de 243, es decir, más de treinta años después de la dictación de la Constitutio, y que dan cuenta de la afirmación del procónsul romano que señala que teme que su presencia en la ciudad pueda confrontarse con alguna "ley de la ciudad"128. Es decir, el magistrado romano reconoce que las leyes locales de Afrodisia aún tienen vigencia para la misma ciudad. El doctor Bancalari agrega otros casos que

${ }^{121}$ Véase: Menandro, el rétor, Dos tratados de retórica epidíctica, Tratado I, III, 363, 11-14 y III, 364, 14.

${ }^{122}$ Véase: Menandro, el rétor, Dos tratados de retórica epidíctica, Tratado I, III, 365, $13-14$

${ }^{123}$ Roma es nuestra patria común. Véase: Modestino, Digesto 50,1,33.

${ }^{124}$ Gregorio es casi contemporáneo a la emisión de la misma. Véase: VAN DAM, Raymond, Hagiography and History: the life of Gregory Thaumaturgus, en Classical Antiquity 1 (1982) 2, pp. 272-308.

${ }^{125}$ Véase: Spagnuolo Vigorita, Tullio, cit. (n. 113), p. 224.

${ }^{126}$ Véase: Bancalari, Alejandro, Coexistencia o enfrentamiento, cit. (n. 17), pp. 25-39.

${ }^{127}$ Véase: D’ORs, Álvaro, La formación del “ius novum” en la época tardo clásica, en Revista de Estudios Histórico-Jurídicos 4 (1979), pp. 35-49.

${ }^{128}$ Véase: BANCALARI, Alejandro, Coexistencia o enfrentamiento, cit. (n. 17), p. 32. 
se pronuncian a favor de la progresiva adopción de las instituciones jurídicas romanas por sobre los derechos locales ${ }^{129}$.

La conclusión del estudio del doctor chileno es que "no hubo entonces un "monismo jurídico", que habría regido en el Imperio a comienzos del siglo III, idea que solo es fruto de un entusiasmo panegirístico. Hubo, en cambio, una cierta "autonomía jurídica", que garantizó continuidad con las tradiciones indígenas y peregrinas. Contra la opinión difundida, la varietas iuris se conservó por algunos siglos en todo el Imperium Romanum, tanto en el oriente como en el occidente"130.

Con todo, la historiografía no ha dicho la última palabra. El siglo XX, tan prolífico en el estudio de los documentos contenidos en papiros nos brindó mayores luces sobre un tema de suyo complejo, pero a la vez, cautivador. Es efectivo lo que dice el doctor Bancalari al respecto ${ }^{131}$, a lo que nosotros agregaríamos que, tal vez, haya llegado la hora de que la historiografía jurídica que por tanto tiempo ha descuidado el análisis de estos asuntos nos proporcione nuevos enfoques y aporte aire fresco a la controversia que hemos reseñado brevemente.

\section{Pérdida de la ciudadanía durante el Imperio.}

Más allá de las formas consagradas en el derecho arcaico ${ }^{132}$, lo que nos interesa es observar que la ciudadanía durante el principado se ha vuelto un bien tan universal que resulta difícil concebir a un hombre libre que no goce de ella. En esto podemos encontrar un paralelo evidente con los estados modernos. Desde la generalización de la ciudadanía en virtud de la Constitutio de Caracalla, las causales de pérdida de la ciudadanía están reservadas o más bien confinadas al ámbito del derecho penal. Así solo puede privarse de la ciudadanía a quienes hayan sido sancionados con la pena de deportatio in insulam ${ }^{133}$ o los trabajos forzosos de por vida, en obras públicas. Ambas importan la pérdida de la condición ciudadana debido a que el afectado se vuelve dediticio ${ }^{134}$.

\section{EL OCASO DE LA CIUDADANÍA, DEL CIUDADANO EN LA CRISIS DEL SIGLO III AL SÚBDITO ROMANO DEL FINAL DEL IMPERIO}

La Constitutio Antoniniana marca el paso desde un universo político oficialmente plural, hacia un orden más pleno en relación a sus integrantes, que adquieren el derecho de la ciudadanía, para valerse del mismo entre sí y ante la autoridad romana. Sin embargo, resulta paradojal que precisamente a partir de la concesión universal de la ciudadanía, el sistema político romano se haya degradado desde el Principado, que reconocía formalmente la vigencia de las instituciones

\footnotetext{
${ }^{129}$ Ibíd., p. 33-35.

${ }^{130}$ Ibíd., p. 39.

${ }^{131}$ Ibíd.

${ }^{132}$ Adecuadamente nos las recuerda GUZMÁn BRITO, Alejandro, Derecho privado romano (Santiago, 1996), I, pp. 330 s.

${ }^{133}$ Exilio o confinamiento en una isla desierta.

${ }^{134}$ Digesto, 48,19,2,1 y 48,19,17,1.
} 
republicanas, hasta un nuevo régimen que la historia ha llamado "Dominado" en referencia a su evidente filiación de autocracia oriental. En razón de ello el ciudadano pierde el derecho de saludar al gobernante como hombre libre, cuyo atributo distintivo es la ciudadanía, y se reemplaza el "salve o Ave César" por la llamada prosternación o proskinesis oriental, en donde el gobernante recibe la pleitesía de los súbditos, que se consideran verdaderos sirvientes o incluso esclavos del soberano y no le saludan de pie como antes, sino tocando el suelo con la frente en una actitud de completa sumisión. Con Diocleciano el proceso de conversión del ciudadano romano al súbdito estará casi completo ${ }^{135}$. El triunfo del cristianismo en el Imperio, no evitará que los emperadores asuman la dignidad y ciertos atributos propios de la divinidad.

De hecho, el último de los grandes emperadores, Teodosio el Grande, de origen Hispano y que proclamó al Cristianismo como religión oficial del Imperio ${ }^{136}$, fue también el último en considerar a sus súbditos como ciudadanos, relacionándose con ellos como su igual, como atestigua el Panegírico de Pacato ${ }^{137}$. La actitud de Teodosio ciertamente podría resultar anacrónica, dadas las circunstancias en que se desarrolló su gobierno, pero se explica el prestigio que aún despertaba esta forma de concebir la relación entre gobernante y gobernados ${ }^{138}$.

En efecto, no obstante la transformación en las costumbres políticas, los intelectuales de esta época de decadencia aún evocaban la fuerza de una ciudad de Roma que se había transformado en una civilización mundial compuesta de hombres libres y responsables ante los demás. Resulta muy interesante considerar que la idea de la ciudadanía como construcción cultural perduraría mucho más de la subsistencia de la noción jurídica de la misma.

${ }^{135}$ Con todo, en el imaginario colectivo de las clases educadas del imperio, los ideales políticos del principado serán defendidos aún en una época tan tardía como en el reinado de Juliano el apóstata. En su Epitafio a Juliano, el rétor Libanio rescata los ideales de la defensa de la cultura clásica, la idea del Imperio, el principio de gobierno de derecho sujeto a la ley y la existencia del principado, pese a que es consciente de que esta forma de gobierno ya no existe en su tiempo. Véase: MuÑIz G., Elena, El ideal imperial en la obra de Libanio, en Habis 31 (2000), pp. 355-363.

${ }^{136}$ La idea de que el Cristianismo como religión oficial produce una suerte de persecución de los paganos está presente en el estudio de Enjuto S., Begoña, Julio Constancio, paladín de la aristocracia romana del siglo IV D.C., en Habis 32 (2001), pp. 495-503. Discrepamos de esta tesis, en efecto, Julio Constancio se erige en defensor de los derechos de la aristocracia pagana, pero su fracaso se prueba precisamente debido a la inexistencia de un grupo pagano de significación social en su tiempo.

137 "Nuestro príncipe, en cambio, se ofrece a las miradas de todos y la gente puede ver tan a menudo a nuestro emperador como el día o el sol". Pacato destaca este aspecto de la personalidad de Teodosio, precisamente para diferenciarle de otros gobernantes anteriores que consideran a los romanos como meros siervos. Al respecto, consultar PARETI DE CANESA., María Eugenia, Teodosio ante la aristocracia pagana de Roma (Según el panegírico de Pacato), en Semanas de Estudios Romanos (2004), XII, pp. 213-232.

${ }^{138}$ Sobre el reinado de Teodosio consultar: HubEÑAK, Florencio, El hispano Teodosio y la cristianización del Imperio, en Hispania Sacra 51 (1999) 103, pp. 5-42; y Lomas Salmonte, Francisco Javier, Teodosio, paradigma de príncipe cristiano: Consideraciones de Ambrosio, Rufino de Aquileya y Agustín sobre la imperial persona, en Studia Historica. Historia Antigua 8 (1990), pp.149-166. 
Christopher Dawson estudió con su tradicional perspicacia este punto de la llamada antigüedad tardía, a la que ya no identifica plenamente con el mundo clásico ${ }^{139}$ : "Para el hombre ordinario el Estado no era el Imperio romano, sino su ciudad nativa. Fue en la medida en que la burocracia imperial se iba apoderando de la antigua administración citadina como los individuos se convirtieron en miembros del Imperio/ De este modo, la desaparición de la antigua constitución citadina no fue una irreparable pérdida, pues venía acompañada de la expansión de la ciudadanía imperial. El siglo III, que vio el surgimiento del Estado burocrático centralista, presenció también la propagación de la ciudadanía romana a las poblaciones provinciales, así como la transformación de la ley romana, exclusiva de una clase privilegiada a la ley común del Imperio. Y esta evolución (de la ciudadanía romana) no fue motivada solamente por la intención del gobierno central de reforzar el control de sus súbditos, sino que también surgió de los ideales sociales y políticos de la época./ [...] Aun en la etapa más oscura del Imperio tardío, estas ideas nunca desaparecieron completamente. Los romanos sentían que el Imperio estaba en todo lo que hubiera en el mundo de civilización, justicia y libertad, y hasta el siglo VII gustaban repetir el antiguo dicho de que entre los gobernantes de la tierra solamente el emperador romano reinaba sobre hombres libres, mientras que los jefes de los bárbaros dominaban esclavos"140

En el pensamiento de los romanos de la decadencia, de la crisis citadina y del eclipse del mundo antiguo, estaban muy presentes los caracteres del patriotismo y de la valoración de la civilización urbana, cultura de ciudadanos que tan querida había sido para sus antepasados de los dos siglos anteriores ${ }^{141}$.

Son notables dos ejemplos de lo que afirmamos: El caso del político y literato de origen galo Rutilio Namaciano ${ }^{142}$ y el del poeta egipcio Claudiano ${ }^{143}$.

El primero afirma: "Fecisti patriam diversis gentibus unam: profuit iniustis ${ }^{\underline{8}}$ te

${ }^{139}$ Dawson, Christopher, cit. (n. 1), p. 91, introduce un matiz que no necesariamente compartimos, al indicar que en los tiempos clásicos el Imperio era identificado con una potencia extranjera sobre sociedades conquistadas.

${ }^{140}$ Ibíd., pp. 91-93.

${ }^{141}$ Esta convicción recorre la mentalidad de pensadores cristianos y paganos por igual, podemos buscar su presencia desde Prudencio a San Agustín.

${ }^{142}$ Rutilio Namaciano, fue un político romano de origen galo que vivió desde fines del siglo IV al inicio del siglo V. Fue prefecto de Toscana y Umbría y finalmente de Roma entre el 413 y 414 . Autor de numerosos opúsculos, el único que ha sobrevivido hasta nuestros días es el llamado De reditu suo, El regreso, un diario de viaje en el que narra su regreso, desde Roma a su tierra natal en Tolosa. Se trata de un gran defensor de la historia de Roma, crítico del cristianismo y defensor de las antiguas creencias cívico-religiosas romanas. Para un estudio de las principales facetas del pensamiento de Namaciano véase: RibaGorda, Miguel, La pervivencia religiosa pagana en el siglo V: el ejemplo de Rutilio Namaciano, en Antigüedady Cristianismo, 14 (1997), pp. 179-187. Hay versión electrónica disponible en http://revistas. um.es/ayc/article/view/65321/62941 (12-02-2009).

${ }^{143}$ Claudio Claudiano, fue un poeta romano de origen egipcio alejandrino que desarrolló su labor literaria en la corte del emperador Honorio. Tenemos registro de su estadía en Roma desde el 395 al 404. Conservamos una parte de sus numerosas obras, especialmente discursos y panegíricos. La obra que aquí citamos corresponde a una descripción elogiosa del general Estilicón, verdadero poder detrás del trono en la época del poeta. 
dominante capi. Dumque offers victis proprii consortia iuris, urbem fecisti quod prius orbis erat" 144 . Y manifiesta su confianza en que a pesar de sus males la ciudad prevalecerá en contra de sus enemigos: "ordo renascendi est crescere posse malis" $145 \mathrm{Se}$ trata de una vigorosa defensa del ideal ciudadano, de la idea de una Roma como patria común de todos los hombres, de una cultura de ciudadanos libres. Aunque evidentemente en un tiempo en donde dichos ideales no son ya aplicados en la vida política real. La idea de Roma era en la mente de Namaciano, más fuerte de la degradada realidad política en la que el Senador vivía.

En el caso de Claudiano, al reflexionar sobre el mismo punto señala: "haec est in gremium victos quae sola recepit humanumque genus communi nomine fovit matris, non dominae ritu, civesque vocavit quos domuit nexu pio longinqua revinxit" ${ }^{146}$.

En la misma línea se pronuncian los autores cristianos de la época como Prudencio, que estima que los romanos de su época viven 'como ciudadanos de una misma sociedad civil y como miembros de la misma casa' ${ }^{147}$.

Digamos finalmente, que el fenómeno de la transformación del ciudadano en súbdito coincide, o incluso es consecuencia directa, de la crisis de la vida urbana $^{148}$. Las ciudades, especialmente en la mitad occidental del Imperio se ven enfrentadas a tal tipo de problemas que no logran ya soportar el peso de mantener a su población ${ }^{149}$. La pesada fiscalidad impuesta sobre ellas desde antes de los Severos, producirá un permanente déficit presupuestario y preparará el

${ }^{144}$ Rutilio Namaciano, De reditu suo, I,63-66: "Para las naciones separadas unas de las otras has construido una sola patria; bajo el cautiverio de tu dominio que tuvo beneficios para todos, incluso para aquellos que no conocieron la justicia y que ofreciendo a los derrotados una parte de tu propia justicia, has cimentado una ciudad de lo que antes fue un mundo".

${ }^{145}$ Rutilio Namaciano, De reditu suo, I,140: "El poder de crecer en las desgracias es la ley de la supervivencia”.

${ }^{146}$ Claudio Claudiano, De consulatu Stilichonis, III,24,151-154: "Ella sola es la que ha recibido a los conquistados en su seno y ha nutrido al género humano bajo un mismo nombre, no como una emperatriz sino como una madre para compartir su ciudadanía y uniendo pueblos lejanos con vínculos de afecto”.

${ }^{147}$ Hemos parafraseado a Aurelio Prudencio Clemente (348-410), pensador de la segunda mitad del siglo IV, aunque, en su pensamiento, el factor que explica el sentimiento de "patria común” es el cristianismo, el imperio de Cristo.

${ }^{148}$ Estimamos que la conocida tesis de Rostovtzeff, Mijail, cit. (n. 57), II, pp. 386 ss., resulta plenamente confirmada por la interpretación historiográfica más reciente, la crisis del tardo Imperio fue ante todo una crisis de la vida ciudadana. Es la misma idea que se encuentra presente en la obra de Pablo Orosio, que reconoce la decadencia de la urbe, no obstante el talante optimista que manifiesta por el carácter cristiano de la sociedad de su época. dice Orosio Paulo, Siete libros de Historia contra los paganos, II,3,3: "similiter et Roma post annos totidem, hoc est MCLX et [fere] quattuor, a Gothis et Alaricho rege eorum, comite autem suo, inrupta et opibus spoliata non regno, manet adhuc et regnat incolumis" ["Pues bien, de la misma forma, Roma, tras un número igual de años, es decir, mil ciento sesenta y casi cuatro más, ha sido atacada y privada de sus riquezas, aunque no de su imperio, por los godos y por Alarico, rey de aquéllos, y por el prefecto de la ciudad; a pesar de ello se mantiene todavía incólume”: Esta traducción castellana ha sido tomada de la edición de Editorial Gredos, (Madrid, 1982), p. 144].

${ }^{149}$ Véase: Padilla M., Aurelio, La transferencia de poder de Gades a Asido. Su estudio a través de la perspectiva social, en Habis 21 (1990), pp. 241-258. 
escenario para la crisis de la despoblación de las mismas a partir de fines del siglo III e inicios del IV ${ }^{150}$.

El cambio de la corte imperial en Occidente, desde la vieja Roma, agotada por la crisis demográfica y social, hasta la sede fortificada en Milán y luego en Rávena y Aquilea marca el paso de la vida cívica, cuyos protagonistas son los cives, hasta la vida de señorío en donde los hombres libres son súbditos de un señor o rey ${ }^{151}$.

\section{CONCLUSIONES}

a) Nuestro análisis ha pretendido destacar la importancia y consecuencias culturales que tuvo para la sociedad clásica, la expansión de la ciudadanía romana. Lo que Roma logró a través de ésta, tras un proceso largo y profundo, fue un triunfo cultural que no ha podido ser emulado a lo largo de los siglos.

b) Roma logra dejar de ser una ciudad y expandirse hasta ser confundida, en la mentalidad de los hombres de su tiempo, con el propio mundo, el "orbis terrarum" a que tantas veces a lo largo de estas páginas hemos aludido: "In Orbe Romano qui sunt, ex Constitutione imperatoris Antonini cives Romani effecti sunt" 152 , como afirma la famosa sentencia del jurista clásico Ulpiano, no es un tópico que represente un ideal político meramente teórico, sino la constatación histórico cultural de la victoria civilizadora de Roma. Dos siglos después, San Agustín insistirá en la cuestión en la dirección que comentábamos antes: "fieret [...] ut omnes ad Romanum imperium pertinentes societatem acciperent civitatis et Romani cives essent ac sic esset omnium, quod erat ante paucorum" 153 .

c) Desde los Julio-Claudios hasta los Severos, cuatro grandes dinastías de gobernantes imperiales mantienen la ampliación general de la ciudadanía. Hay altibajos en cada dinastía, incluyendo a los propios Severos. Pero la dirección hacia la expansión cada vez mayor siempre se mantiene en el largo plazo.

d) El proceso por el cual la ciudadanía romana se vuelve universal concluye formalmente con los Severos, la famosa dinastía de origen africano. En su tiempo, estos emperadores todavía debieron luchar en contra de los prejuicios de la dirigencia del Imperio que aún consideraba que un no itálico de origen resultaba poco grato a la civilización romana. Con todo, los Severos se beneficiaron de la fructífera política de los Antoninos, y aunque efectivamente no siempre fueron bien recibidos en el poder (incluyendo a sus familias) y varios de ellos fueron duramente criticados por sus orígenes "extranjeros", terminando su reinado trágicamente, no

${ }^{150}$ Sobre el particular, véase: García Moreno, Luis A., La Antigüedad, cit (n. 41), p. 448 s. Además el estudio clásico de GANGHOFFER, R., L'évolution des institutions municipales en Occidente et en Orient au Bas-Empire (París, 1963).

${ }^{151}$ Un interesantísimo análisis sobre el punto de la crisis de la vida en la ciudad se encuentra en la obra de CECCONI, Giovanni Alberto, Governo imperiale e élites dirigenti nell'Italia tardoantica. Problemi di storia politico-amministrativa (270-476 d.C.) (Como, 1994).

${ }^{152}$ Ulpiano, Digesto, I, 5,17.

${ }^{153}$ San Agustín, La Ciudad de Dios, V,17: "Mayormente [...] ordenando que todos los vasallos que pertenecían al Imperio romano gozasen de la naturaleza y privilegio de la ciudad, disfrutando el honor de los ciudadanos romanos, siendo así común a todos la prerrogativa que antes era peculiar de muy pocos". 
es menos cierto, que tanto el fundador de la dinastía, Septimio Severo, como el último de sus representantes, Alejandro, fueron considerados por sus contemporáneos y la posteridad como verdaderos modelos del legítimo gobernante romano, plenamente identificados con la civilización a la que dirigieron.

e) Hemos dicho que el legado de la ciudadanía estuvo completo, en lo formal o jurídico con la Constitutio Antoniniana de Caracalla. Sin embargo, la herencia cultural que esta expansión de la ciudadanía representa, no concluyó ni se extinguió del patrimonio común de ideas de Occidente hasta nuestros días.

6. Desde el punto de vista de la identidad cultural imperial, el símbolo de la misma, es la pax Romana. Es la condición civilizadora que Roma impone pacíficamente al difundir los ideales de su cultura a todos los pueblos que gobierna. Como en su momento sostuvo el rétor Elio Arístides, este es un poder que no cae en el despotismo, es más bien una potestad ordenadora y rectora por la cual Roma encabeza a una serie de pueblos libres bajo su mandato, que poco a poco se vuelven romanos ${ }^{154}$.

f) La condición de ciudadano permite a los hombres libres disfrutar de un estatus político, social y cultural equivalente a lo largo de todo el imperio y el orden jurídico que Roma establece llega a ser territorial. Una de las consecuencias de esta expansión de la ciudadanía es borrar las distinciones jurídicas entre los habitantes del imperio, pero más importante aún, es la implantación de una forma de vida, un modo de ver el mundo y de contemplarse a sí mismos que es propio y distintivo de los ciudadanos romanos ${ }^{155}$ donde quiera que éstos vivan y cualquiera que sea su origen.

g) Con posterioridad al reinado de los Severos, la idea de una patria fundada en la ciudadanía, un mundo ciudadano ${ }^{156}$, será tan fuerte, que incluso en los tiempos del Bajo Imperio, se repetirá una y otra vez entre los escritores e intelectuales de la última etapa de Roma. En el reinado de Teodosio, hay un intento concreto por rescatar la noción cultural de ciudadanía y de ciudadanos, en una época en que ya se abría paso la idea del súbdito. Roma nos legaba la idea de una civilización universal ${ }^{157}$.

${ }^{154}$ Véase: Elio Arístides, Discurso a Roma, 36,8-12.

${ }^{155}$ Véase: Veyne, Paul, "Humanistas": los romanos y los demás, en Giardina, Andrea (editor), El hombre romano (Madrid, 1989), p. 420. Debemos reconocer la importancia de aquellas diferencias sociales, pero ello no debe hacernos olvidar que el triunfo de Roma consiste precisamente en lograr que tales diferencias cedan en importancia frente a la unificación cultural, política y jurídica más amplia, al estilo de lo que podríamos concebir como una amplia cobertura que prestaba su protección a diversos trajes o particularidades de origen.

${ }^{156}$ En las lúcidas palabras de Florence Dupont: "Civis, civitas, civilis, este vocabulario latino ha dejado huellas del parentesco que unía a Roma, ciudad y civilización. Pues la ciudad romana no es solamente un régimen político; la ciudad es una cultura y, para los antiguos, tanto romanos como griegos, no hay hombre civilizado sino en las ciudades". Véase: DuPONT, Florence, cit. (n. 18), p. 26.

157 “La nueva Roma cristiana, cuyo advenimiento había saludado Prudencio, en verdad estaba destinada a heredar la tradición romana y a preservar el antiguo ideal de unidad romana en un mundo que no era ya el mismo. Fue, pues, a Roma a quien los nuevos pueblos debieron la idea misma de una civilización común.

En el caos de los siglos oscuros que estaban por venir los hombres añoraron el recuerdo de la paz y el orden universales logrados por el Imperio romano, con su religión, ley y cultura 
[Recibido el 23 de mayo y aprobado el 4 de julio de 2009].

\section{BIBLIOGRAFÍA}

FUENTES PRIMARIAS:

Agustín, San, La Ciudad de Dios.

Claudio Claudiano, De Consulatu Stilichonis.

Dión Casio, Historia de Roma.

Elio Arístides, Discursos.

Elio Esparciano - Julio Capitolino - Elio Lampridio y otros, Historia Augusta.

GAYO, Institutiones.

Herodiano, Historia del imperio romano después de Marco Aurelio.

Justiniano, Cuerpo del Derecho Civil Romano, Instituciones y Digesto.

Latinio Pacato Drepanio, Panegyricus Latini Pacati Drepani dictus Teodosio.

Menandro el rétor, Dos tratados de retórica epidíctica.

Paulo Orosio, Siete libros de Historia contra los paganos.

Rutilio Namaciano, De reditu suo, I.

OBRAS GENERALES Y MONOGRAFÍAS:

Alvarado Planas, Javier - Montes Salguero, Jorge - Pérez Marcos, Regina - Sánchez GonzÁlez, María Dolores, Manual de Historia del Derecho y de las Instituciones (Madrid, 2006).

Azcárraga, Joaquín de - Pérez-Prendes Muñoz de Arraco, José Manuel, Lecciones de Historia del Derecho Español (3a edición, Madrid, 1997).

Barrientos Grandón, Javier, Introducción a la Historia del Derecho chileno, Derechos Propios y Derecho Común en Castilla (Santiago, 1994), I.

Barrientos Grandón, Javier, Curso de Historia del Derecho (Santiago, 2003), I.

Bermejo Barrera, José Carlos - Piedras Monroy, Pedro Andrés, Genealogía de la Historia, ensayos de historia teórica (Madrid, 1999), III.

Bickermann, E., Das Edickt des Kaisers Caracalla in P. Giessen 40 (Berlín, 1926).

Calderini, Aristide, I Severi. La crisi dell'Impero nel III Secolo (Bolonia, 1949).

Coronas González, Santos M., Manual de Historia del Derecho español (Valencia, 1996).

CECCONI, Giovanni Alberto, Governo imperiale e élites dirigenti nell'Italia tardoantica. Problemi di storia politico-amministrativa (270-476 d.C.) (Como, 1994).

Dawson, Christopher, Historia de la cultura cristiana (1950, trad. cast. México, 1997).

D'Ors, Álvaro, Constitutio Antoniniana (P. Giss. 40, I). Contribución al estudio de su valor y significado para la historia del Derecho Romano (Madrid, 1941).

Díaz-Plaja, Fernando, La vida cotidiana en La España Romana (Madrid, 1995).

Dupont, Florence, El Ciudadano romano, durante la República (Buenos Aires, 1992).

comunes, y los reiterados esfuerzos de la Edad Media por volverse: al pasado y recuperar la unidad y civilización perdidas empujaron a los nuevos pueblos hacia el futuro y prepararon el camino para el advenimiento de una nueva cultura europea", véase: DAwsOn, Christopher, cit. (n. 1), p. 95. 
Errázuriz Eguiguren, Maximiano, Historia Externa de Roma, del Acto Jurídico, de las Personas (2a edición, Santiago, 1989), I.

Escudero, José Antonio, Curso de Historia del Derecho. Fuentes e Instituciones Politicoadministrativa (2a edición, Madrid, 1995).

Ganghoffer, R., L'évolution des institutions municipales en Occidente et en Orient au Bas-Empire (Paris, 1963).

García Moreno, Luis y otros, Historia del mundo clásico a través de sus textos, II: Roma (Madrid, 1999).

García Moreno, Luis A., La Antigüedad clásica, el Imperio Romano (Pamplona, 1989), II.

Giardina, Andrea, El hombre romano (Madrid, 1989).

Grant, Michel, The Severans: The Changed Roman Empire (New York, 1996).

GuZMÁn BRITO, Alejandro, Derecho privado romano (Santiago, 1996), I.

IGLESIAS-REDONDO, Juan, Repertorio bilingüe de definiciones, reglas y máximas jurídicas romanas (Madrid, 1986).

JARDÉ A., Etudes critiques sur la vie et le règne de Sévère Alexandre (Paris, 1925).

Le Gall, Joel - Le GlaY, Marcel, El Imperio Romano (Madrid, 1995).

Levaggi, Abelardo, Manual de Historia del Derecho Argentino (Castellano-Indianol Nacional). Parte general (Buenos Aires, 1991), I.

Levi, Mario Atilio, La Città Antica (Roma, 1989).

Mangas, Julio, Historia Universal. Edad Antigua, Roma (Barcelona, 1999).

MAZZA, M., Istituzioni giuridiche e realtà politiche nel Tardo Impero (III-V sec. D.C.) (Milán, 1976).

MeYer, P. M., Griechische Papyri im Museum des Giessen 2 (Lepzig-Berlín, 1910).

Millar, Fergus (editor), Historia universal siglo XXI, VIII: El Imperio Romano y sus pueblos limitrofes, el mundo mediterráneo en la edad antigua (México, 1975), IV.

Mommsen, Theodor, El mundo de los césares (2a edición, 1941, trad. cast. México, 2006).

Piganiol, André, Historia de Roma (1939, trad. cast. Buenos Aires, 1981).

RostovtzeFf, Mijail, Historia social y económica del Imperio Romano (Madrid, 1998), I y II.

Salvat Monguillot, Manuel, Breve Historia del estudio del Derecho (Santiago, 2001).

SáncheZ-Arcilla Bernal, José, Historia del Derecho español (Zaragoza, 2001).

SÁnChez-ArCilla Bernal, José, Historia del Derecho. Instituciones politico-administrativas (Madrid, 1995), I.

SCARre, Chris, Chronicle of the Roman Emperors, The Reign-by-Reign Record of The Rulers of Imperial Rome (London, 1997).

SchÖNBAuER, Ernst, Reichsrecht gegen Volksrecht? Studien über die Bedeutung der Constitutio Antonina für die röm. Rechtsentwicklung (s.1.,1931).

Spagnuolo-Vigorita, Tullio, Diritti locali e modello romano nel principato, en GonZÁLEZ F., Julián (editor), Roma y las provincias, realidad administrativa e ideología imperial (Madrid, 1994).

SQuilloni, Antonella, Il concetto di regno nel pensiero dello Pseudo Ecfanto: Le fonti e $i$ trattati peri basileias (s.l., 1988).

Valdeavellano, Luis G. de, Curso de Historia de las Instituciones españolas, de los orígenes al final de la Edad media (3a edición, Salamanca, 1992). 
Veyne, Paul, "Humanistas": los romanos y los demás, en Giardina, Andrea (editor), El hombre romano (Madrid, 1989).

WolfF, Hartmut, Die “Constitutio Antoniniana” und Papyrus Gissensis 40.I. (Colonia, 1975).

ARTÍ́CULOS DE REVISTAS ESPECIALIZADAS:

ANDRADEs Rivas, Eduardo, La ciudadania romana bajo los Julio-Claudios en Revista de Estudios Histórico-Jurídicos 29 (2007).

ANDRADEs Rivas, Eduardo, La ciudadanía romana bajo los Flavios y Antoninos en Revista de Estudios Histórico-Jurídicos 30 (2008).

Arnold, E. V., Classics and Citizenship, en The Classical Quarterly 14 (1920) 2, pp. 78-81.

BANCAlaRI, Alejandro, La "civitas" romana en Livio Druso y Caracalla: aspectos de sus proyectos y realizaciones, en Tiempo y Espacio 7-8 (1997-1998).

BANCALARI, Alejandro, La "Constitutio Antoninina": aproximaciones significado y características, en Semanas de Estudios Romanos (1998), IX.

BanCAlari, Alejandro, Relación entre la "Constitutio Antoniniana" y la "Imitatio Alexandri" de Caracalla, en Revista de Estudios Histórico-Jurídicos 22 (2000).

BANCALARI, Alejandro, Coexistencia o enfrentamiento entre el Derecho romano y los derechos locales de las provincias, en Revista de Estudios Histórico-Jurídicos 26 (2004).

Bell, H. I., The Constitutio Antoniniana and the Egyptian Poll-Tax, en The Journal of Roman Studies 37 (1947) 1-2. Versión digital en: http://www.jstor.org/stable/298450.

Benario, Herbert W., The "Dediticii" of the "Constitutio Antoniniana", en Transactions and Proceedings of the American Philological Association 85 (1954).

Birley, Anthony R., Septimius Severus, the African Emperor (2a edición, Londres, 1999). Versión digital en: http://books.google.cl/books?id=Obu1zSDuUYsC\& $\mathrm{dq}=$ BIRLEY,

+ A., + Septimius + Severus,+ the + African + Emperor \&printsec $=$ frontcover \&so urce $=$ bn \&hl =es\&ei=3pXsSe6MIYWjtgef69HEBQ\&sa =X\&oi=book_ result \&ct $=$ result $\&$ resnum $=4$.

Blásquez Martínez, José María, Leptis Magna. Patria de Septimio Severo, en Revista de Arqueología 250 (2001), pp. 32-43, versión digital en: http://descargas.cervantesvirtual.com/servlet/SirveObras/02580625333584673432268/031861.pdf?incr=1.

Burkert, W., “Peri Basileias”, en Pseudoepigrapha, I: Entretiens surl'Antiquité classique 28 (1972).

D'Ors, Álvaro, La formación del “ius novum” en la época tardo clásica, en Revista de Estudios Histórico-Jurídicos 4 (1979).

Enjuto S., Begoña, Julio Constancio, paladin de la aristocracia romana del siglo IV D.C., en Habis 32 (2001).

Fernández Ardanaz, Santiago - González Fernández, Rafael, El “consensus" y la "auctoritas" en el acceso al poder del emperador Septimio Severo, en Antigüedady cristianismo 23 (2006), pp. 23-37. Versión digital en: http://interclassica.um.es/ investigacion/hemeroteca/antigueedad_y_cristianismo/ numero_23_2006/ el_consensus_y_la_auctoritas_en_el_acceso_al_poder_del_emperador_septimio_severo.

Gilliam, J. F., Dura rosters and the Constitutio Antoniniana, en Historia 14 (1965).

Giua, Maria Antonietta, Recensión a Dondin-Payre, Monique - Raepsaet-Chanlier, 
Marie-Thérèse (editoras), Noms. Identités culturelles et Romanisation sous le HautEmpire, en Athenaeum-Studi di Letteratura e Storia dell'Antichità 92 (2004) 1.

Heichelheim, F. M., The text of the "Constitutio Antoniniana" and the Three other Decrees of the Emperor Caracalla Containes in Papyrus Gissensis 40, en The Journal of Egyptian Archaeology 26 (1941); version digital en: http://www.jstor.org/ pss $/ 3854517$.

Hubeñak, Florencio, El hispano Teodosio y la cristianización del Imperio, en Hispania Sacra 51 (1999) 103.

Jones, A. H. M., Another Interpretation of the 'Constitutio Antoniniana', en The Journal of Roman Studies 26 (1936) 2.

Kagan, Kimberly, Redefining Roman Grand Strategy, en The Journal of Military History 70 (2006) 2, pp. 333-362; versión digital en: http://www.jstor.org/ stable/4137956.

Keresztes, Paul, The "Constitutio Antoniniana" and the Persecutions under Caracalla, en The American Journal of Philology 91 (1970) 4; versión digital en: http://www. jstor.org/stable/293084.

Lawton Sherman, Charles, The "Constitutio Antoniniana" in the Light of the "Gnomon Tou Idiou Logou", en Transactions and Proceedings of the American Philological Association 59 (1928).

Lomas Salmonte, Francisco Javier, Teodosio, paradigma de príncipe cristiano: Consideraciones de Ambrosio, Rufino de Aquileya y Agustín sobre la imperial persona, en Studia Historica. Historia Antigua 8 (1990).

Millar, Fergus, The date of the "Constitutio Antoniniana", en The Journal of Egyptian Archaeology 48 (1962); versión digital en: http://www.jstor.org/stable/3855791.

Muñiz G., Elena, El ideal imperial en la obra de Libanio, en Habis 31 (2000).

Padilla M., Aurelio, La transferencia de poder de Gades a Asido. Su estudio a través de la perspectiva social, en Habis 21 (1990).

Pareti de CAnesa., María Eugenia, Teodosio ante la aristocracia pagana de Roma (Según el panegírico de Pacato), en Semanas de Estudios Romanos (2004), XII.

Pérez Almogera, Arturo, "Civitates" y etnias epónimos en el área ibérica: las excepciones (Contestani, Lacetani, Cerretani), en Florentia Iliberritana. Revista de Estudios de Antigüedad Clásica 11 (2000).

Ribagorda, Miguel, La pervivencia religiosa pagana en el siglo V: el ejemplo de Rutilio Namaciano, en Antigüedad y Cristianismo 14 (1997); versión digital en: http:// revistas.um.es/ayc/article/view/65321/62941.

VAN DAM, Raymond, Hagiography and History: the Life of Gregory Thaumaturgus, en Classical Antiquity 1 (1982) 2.

\section{FUENTES ELECTRÓNICAS:}

Fernández, Gonzalo, Un historiador pagano del siglo IV D.C. Sexto Aurelio Víctor, en Arbil 120, publicación electrónica: http://www.arbil.org/120sext.htm (2004-2009).

JSTOR: http://www.jstor.org. 
